Wewarah: Jurnal Pendidikan Multidisipliner

Volume 1 (1) 125 - 147 Januari 2021

The article is published with Open Access at http://e-journal.unipma.ac.id/index.php/WEWARAH

\title{
Pemanfaatan Akun Belajar.id Kemdikbud pada Masa Pandemi Covid 19
}

\author{
Suyati Nur Rahma, Universitas PGRI Madiun \\ Bambang Eko Hari Cahyono, Universitas PGRI Madiun \\ Sigit Ricahyono, Universitas PGRI Madiun
}

suyatirahma57@edu.com

\begin{abstract}
Abstrak: Penelitian ini bertujuan untuk memperoleh deskripsi yang jelas tentang pembelajaran dengan memanfaatkan akun belajar.id Kemdibud pada pembelajaran bahasa Indonesia pada masa pandemi covid 19 pada siswa kelas 6 SDN Margomulyo 1 Ngawi. Metode yang digunakan adalah deskriptif kualitatif. Sumber data yang digunakan adalah informan, peristiwa, dan dokumen. Informan dalam penelitian ini adalah guru, siswa kelas 6, dan wali murid kelas 6. Peristiwa dalam penelitian ini adalah pelaksanaan pembelajaran bahasa Indonesia pada masa pandemi covid 19. Dokumen penelitian ini adalah RPP, silabus, daftar nilai. Teknik pengumpulan data pada penelitian ini menggunakan wawancara, observasi, dan dokumentasi. Validasi data menggunakan teknik metode triangggulasi dengan sumber. Hasil penelitian menunjukkan bahwa pelaksanaana pembelajaran bahasa Indonesia kelas 6 SDN Margomulyo 1 Ngawi pada masa apandemi covid 19 dapat terlaksana dengan lancar. Pembelajaran lebih efektif, tidak terkendala ruang dan waktu.

Kata kunci: Pemanfaatan Akun Belajar.id Kemdikbud, Pembelajaran Daring

Abstract: This study aims to obtain a clear description of learning by using the Ministry of Education's learning.id account in learning Indonesian during the COVID-19 pandemic for 6th graders at SDN Margomulyo 1 Ngawi.

The method used is descriptive qualitative. Sources of data used are informants, events, and documents. The informants in this study were teachers, 6th grade students, and 6th grade guardians. The events in this study were the implementation of Indonesian language learning during the covid 19 pandemic. The research documents were lesson plans, syllabus, list of grades. Data collection techniques in this study used interviews, observation, and documentation. Validation of the data using the technique of the triangulation method with the source.

The results showed that the implementation of Indonesian language learning for grade 6 at SDN Margomulyo 1 Ngawi during the COVID-19 pandemic could be carried out smoothly. Learning is more effective, not constrained by space and time.
\end{abstract}

Keywords: Utilization of Kemdikbud's Learning.id Account, Online Learning, Pandemic COVID-19

Citation: Rahma, S.N., Cahyono, B.E.H., \& Ricahyono, S. (2022). Pemanfaatan Akun Belajar.id Kemdikbud pada Masa Pandemi Covid 19. Wewarah: Jurnal Pendidikan Multidisipliner, 1(1), 125 - 147.

\section{(cc) EY}

Published by Program Pascasarjana Universitas PGRI Madiun. This work is licensed under the Creative Commons Attribution- NonCommercialShareAlike 4.0 International License. 


\section{PENDAHULUAN}

Virus Corona atau Corona Virus Deseases 19 dikenal sejak Desember 2019. Virus tersebut sangat berbahaya karena penularannya sangat cepat sehigga untuk menghentikan resiko penyebaran virus corona, pemerintah mengeluarkan SOP bahwa pembelajaran dilaksanakan dari rumah. Sehingga demi menjamin kelancaran proses pembelajaran, memudahkan pendidik dan peserta didik mengakses layanan pembelajaran, Kementrian Pendidikan dan Kebudayaan (Kemendikbud) melalui Pusat Data dan Teknologi Informasi (Pusdatin) meluncurkan akun pembelajaran dengan domain belajar.id. Akun elektronik tersebut dapat digunakan oleh peserta didik, pendidik, dan tenaga kependidikan untuk mengakses layanan pembelajaran berbasis elektronik.

Untuk memperjelas masalah yang akan diteliti, maka masalah tersebut dirumuskan sebagai berikut, bagaimanakah pemanfaatan akun belajar.id Kemdikbud pada pembelajaran Bahasa Indonesia siswa kelas 6 SDN Margomulyo 1 pada masa pandemi Covid 19? Berdasarkan rumusan masalah di atas, maka tujuan penelitian ini yaitu mendeskripsikan dan menjelaskan tentang pemanfaatan akun belajar.id Kemdikbud pada pembelajaran Bahasa Indonesia siswa kelas 6 SDN Margomulyo 1 pada masa pandemi Covid 19.

Manfaat diadakannya penelitian ini adalah memberikan informasi mengenai manfaat akun belajar.id Kemdikbud pada pembelajaran Bahasa Indonesia pada masa pandemi covid 19, menjadi rujukan bagi guru untuk memanfaatkan akun belajar.id Kemdikbud pada pembelajaran Bahasa Indonesia, dan memberikan kontribusi pada ilmu pengetahuan khususnya dalam melaksanakan pembelajaran pada masa pandemi covid 19.

\section{Kerangka Berpikir}

Kerangka berpikir tentang pemanfaatan akun belajar.id Kemdikbud pada penelitian ini adalah pembelajaran Bahasa Indonesia menjadi lebih efektif dengan mengakses portal rumah belajar dan semua fasilitas google secara gratis. Salah satunya adalah pemanfaatan google meet dengan durasi waktu yang tidak dibatasi sehingga guru dan siswa dapat berinteraksi layaknya belajar tatap muka. Penyampaian materi dan tanya jawab dengan siswa dilakukan melalui google meet sedangkan pelaksaan ulangan harian dengan menggunakan google form. Meskipun ditemui kendala yaitu ada beberapa siswa tidak bisa memanfatkan akun belajar.id Kemdikbud karena gagal dalam aktivasi akun. Kegagalan aktivasi akun dapat diatasi dengan melaporkan kepada admin pengelola akun.belajar.id Kemdikbud sehingga kendalah tersebut dapat diatasi meskipun harus menunggu beberapa waktu untuk bisa aktivasi kembali. Dengan demikian akun belajar.id Kemdikbud tetap dapat menjadi solusi untuk mengatasi pembelajaran pada masa pandemi covid 19 ini.

\section{Kebaruan Penelitian}

Berikut ini adalah penelitian yang terkait dengan pembelajaran selama pandemi covid 19 dan memanfaatkan portal rumah belajar yaitu portal sebagai sumber belajar yang diluncurkan oleh Kemendikbud dan bisa dimanfaatkan oleh guru dalam pembelajaran daring. Supandri (2018) sudah terlebih dahulu melakukan penelitian tentang portal rumah belajar dengan judul "Faktor-Faktor Penyebab Guru Belum Optimal Memanfaatkan Portal Rumah Belajar Dalam Kegiatan Pembelajaran" dengan metode penelitian deskriptif kualitatif. Variabel penelitian Supandri adalah pemanfaatan portal rumah belajar yang belum optimal dalam kegiatan pembelajaran. Kementrian Pendidikan dan Kebudayaan menurunkan kebijakan-kebijakan tentang pelaksanaan pembelajaran yaitu dengan daring dengan tujuan memutus matarantai penyebaran covid 19.

Pelaksanaan pembelajaran daring sangat dipengaruhi dari kemampuan dari pendidik dalam hal pemanfaatan teknologi serta fitur-fitur yang disediakan oleh Kementrian. Manakala diamati secara seksama, pengaruh/dampak kemajuan TIK yang sangat pesat sangat dirasakan di dalam kehidupan seharihari di bidang pemberitaan/informasi yang memungkinkan orang dapat berkomunikasi dengan mudah, 
cepat, dan relatif murah (Supandri, 2018: 2); dan demikian juga di bidang sistem pendidikan (Supandri, 2018: 2). Namun menurut Indriyanto, dampak positif pemanfaatan kemajuan TIK masih belum tampak pada dunia pendidikan (Supandri, 2018: 2). Sekalipun dikatakan belum tampak dampak positifnya, tetapi berbagai upaya pemanfaatan TIK di bidang pendidikan/pembelajaran telah dimulai secara bertahap dan berkelanjutan. Tidak hanya terbatas pada lembagalembaga pendidikan di daerah perkotaan dan pedesaan saja yang memanfaatkan kemajuan TIK tetapi secara bertahap juga telah mulai dilaksanakan oleh sekolahsekolah yang terdapat di daerah-daerah terdepan, terluar, dan tertinggal (Supandri, 2018: 2).

Lebih jauh dikemukakan Siahaan bahwa pemanfaatan TIK secara arif (terencana, terpadu, dan teratur) dapat memfasilitasi kegiatan pembelajaran, tidak hanya (1) memberikan kemudahan bagi guru dalam membelajarkan peserta didiknya, (2) menjadikan konkrit berbagai uraian objek yang bersifat abstrak, (3) memvisualisasikan secara animatif tahap-tahapan suatu proses atau siklus, tetapi juga (4) meningkatkan efisiensi penggunaan waktu guru untuk menyelenggarakan kegiatan pembelajaran termasuk pemberian berbagai penjelasan (Supandri, 2018: 3).

Seiring dengan kemajuan TIK ini, peran guru telah mengalami perubahan dari yang semula sebagai penyampai pengetahuan, sumber utama informasi, ahli materi, dan sumber segala jawaban menjadi sebagai fasilitator pembelajaran, pelatih, kolaborator, navigator pengetahuan, dan mitra belajar peserta didik (Supandri, 2018: 7). Di samping itu, guru juga bergeser perannya dari yang semula mengendalikan dan mengarahkan semua aspek pembelajaran, menjadi lebih banyak memberikan alternatif dan tanggung jawab kepada peserta didik dalam proses pembelajaran (Supandri, (2018: 7). Guru tidak lagi menjadi satu-satunya orang yang paling tahu terhadap berbagai informasi dan pengetahuan yang berkembang (Supandri, 2018: 7) . Lebih jauh dikemukakan Warsihna bahwa dengan hadirnya Portal "Rumah Belajar" di blantika dunia maya (internet) telah turut menambah khasanah sumber belajar bagi dunia pendidikan di Indonesia.

Kehadiran Portal ini akan memudahkan guru untuk membuat pembelajaran menjadi lebih menarik karena tersedia berbagai komponen yang diperlukan untuk pembelajaran, baik di kelas maupun di luar kelas, terutama penugasan kepada peserta didik agar mereka sedini mungkin mengenal teknologi. Sebagaimana yang telah dikemukakan sebelumnya bahwa Kementerian Pendidikan dan Kebudayaan melalui Pusat Teknologi Informasi dan Komunikasi Pendidikan dan Kebudayaan (Pustekkom Kemdikbud) telah mengembangkan sebuah fasilitas layanan pembelajaran yang terintegrasi dengan pengembangan inovasi pembelajaran dan pembinaan profesionalitas guru disebut sebagai Portal Rumah Belajar (Portal Rumbel) pada tahun 2011 Kemdikbud (Supandri, 2018: 7 ).

Persamaan penelitian Supandri (2018) dengan peneliti terletak pada variabel pembelajaran daring. Sedangkan perbedaannya, Supandri meneliti sebelum masa pandemi covid-19 dengan portal rumah belajar dan peneliti melakukan penelitian pada masa pandemi covid-19 dengan menggunakan akun belajar.id Kemdikbud.

Ulum, dkk (2019) mengadakan penelitian yang berjudul "Pemanfaatan Google Apps di era literasi digital pada siswa Sekolah Dasar (SD)". Metode penelitian menggunakan penelitian deskriptif kualitatif dengan teknik pengumpulan data menggunakan studi kepustakaan. Literasi digital merupakan kemampuan penggunaan teknologi informasi dari perangkat digital secara efektif efisien dalam berbagai konteks kehidupan sehari-hari. Salah satu upaya literasi digital adalah pemanfaatan teknologi informasi menggunakan Google Apps for education yang telah disediakan oleh perusahaan mesin pencari google untuk segenap komponen pendidikan disekolah. Dengan memanfaatkan Google Apps dalam proses pembelajaran yang dapat dibuka melalui smartphone dan tablet, memungkinkan para guru menyiapkan dan menyajikan materi pembelajarannya secara online (dan offline) yang mudah diakses siswa.

Persamaan penelitian yang dilakukan Ulum, dkk (2019) terletak pada kemampuan penggunaan teknologi informasi dari perangkat digital untuk mengembangkan literasi digital sedangkan kebaruan dalam penelitian ini adalah peneliti memanfaatkan teknologi informasi untuk mengakses akun belajar.id Kemdikbud yang dimanfaatkan dalam pembelajaran di era pandemi covid 19. 


\section{METODE}

\section{Pendekatan Penelitian}

Penelitian ini menggunakan pendekatan kualitatif. Menurut Sugiyono (2018: 9) metode penelitian kualitatif adalah metode penelitian yang berlandaskan pada filsafat postpositivisme atau enterpretif, digunakan untuk meneliti pada kondisi obyek yang alamiah, di mana peneliti adalah sebagai instrumen kunci, teknik pengumpulan data dilakukan secara trianggulasi (gabungan observasi, wawancara, dokumentasi), data yang diperoleh cenderung data kualitatif, analisis data bersifat induktif/kualitatif, data hasil penelitian kualitatif bersifat untuk memahami makna, memahami keunikan, mengonstruksi fenomena, dan menemukan hipotesis.

Jenis penelitian pada penelitin ini adalah studi kasus (case study) dengan rancangan single case study (studi kasus tunggal). Studi kasus tunggal (single case study) adalah suatu penelitian yang arah penelitiannya terpusat pada satu kasus atau satu fenomena saja. Dalam studi kasus tunggal umumnya tujuan atau fokus penelitian langsung mengarah pada konteks atau inti dari permasalahan.

\section{Instrumen Pengumpulan Data}

Untuk mencapai semua tujuan penilitian, peneliti perlu menentukan secara tepat jenis data atau informasi yang dibutuhkan karena dapat membantu peneliti menciptakan pertanyaan-pertanyaan dengan kategori respon yang sesuai. Berguna bagi perancang survei untuk memikirkan pertanyaan sebagai pengumpulan informasi dari kategori utama yakni opini, sikap, dan motif; kepercayaan dan persepsi, perilaku, fakta dan atribut, dan pengetahuan (Ulber Silalahi, 2009: 286). Jenis data yang peneliti gunakan adalah:

1. Opini, yaitu pertanyaan tentang opini menanyakan orang apa yang mereka pikir tentang satu isu atau kejadian. Jadi, opini merupakan ekspresi verbal.

2. Perilaku, yaitu pertanyaan tentang perilaku meminta keterangan tentang apa yang telah orang lakukan pada masa lalu, masa sekarang atau baru-baru ini, dan apa yang mereka rencanakan untuk dilakukan pada masa yang akan datang.

3. Fakta, yaitu pertanyaan tentang fakta berhubungan dengan apa yang diketahui dan karakteristik responden atau latar belakang responden, seperti pertanyaan tentang usia, pekerjaan dan lain-lain yang relevan untuk mengetahui perbandingan responden dengan opininya.

4. Pengetahuan, yaitu pertanyaan tentang pengetahuan berkenaan dengan apa yang orang ketahui dalam satu bidang atau satu topik, kedalaman, atau akurasi dari informasi.

\section{Sumber Data}

\section{Jenis Data}

Untuk mencapai semua tujuan penilitian, peneliti perlu menentukan secara tepat jenis data atau informasi yang dibutuhkan karena dapat membantu peneliti menciptakan pertanyaan-pertanyaan dengan kategori respon yang sesuai. Berguna bagi perancang survei untuk memikirkan pertanyaan sebagai pengumpulan informasi dari kategori utama yakni opini, sikap, dan motif; kepercayaan dan persepsi, perilaku, fakta dan atribut, dan pengetahuan (Ulber Silalahi, 2009: 286). Jenis data yang peneliti gunakan adalah:

1. Opini

Pertanyaan tentang opini menanyakan orang apa yang mereka pikir tentang satu isu atau kejadian. Jadi, opini merupakan ekspresi verbal.

2. Perilaku

Pertanyaan tentang perilaku meminta keterangan tentang apa yang telah orang lakukan pada masa lalu, masa sekarang atau baru-baru ini, dan apa yang mereka rencanakan untuk dilakukan pada masa yang akan datang.

3. Fakta 
Pertanyaan tentang fakta berhubungan dengan apa yang diketahui dan karakteristik responden atau latar belakang responden, seperti pertanyaan tentang usia, pekerjaan dan lain-lain yang relevan untuk mengetahui perbandingan responden dengan opininya.

4. Pengetahuan

Pertanyaan tentang pengetahuan berkenaan dengan apa yang orang ketahui dalam satu bidang atau satu topik, kedalaman, atau akurasi dari informasi.

\section{Sumber Data}

Sumber data adalah dari mana data diperoleh. Dalam penelitian ini sumber data yang digunakan adalah sebagai berikut :

Informan

Penelitian ini menggunakan teknik random sampling dalam menentukan informan. Sampel yang digunakan adalah siswa kelas 6, guru kelas 6 serta wali murid dari siswa kelas 6 SDN Margomulyo 1 Ngawi Tahun 2021/2022.

Peristiwa

Peristiwa yang dialami yaitu pembelajaran bahasa Indonesia dengan menggunakan akun belajar.id Kemdikbud. Penjelasan materi dengan google meet, pelaksanaan ulangan harian dengan menggunakan google form. Ada beberapa siswa yang gagal melakukan aktivasi akun belajar.id Kemdikbud. Hal tersebut dapat diatasi dengan menghubungi admin pengelola akun belajar.id Kemdikbud sehingga akun tersebut dapat digunakan.

Dokumen

1. Instrumen wawancara

Suatu bentuk dialog yang dilakukan oleh peneliti untuk memperoleh informasi dari responden dinamakan interview. Instrumennya dinamakan pedoman wawancara atau interview guide. Dalam pelaksanaannya, interview dapat dilakukan secara semi terstruktur, yaitu wawancara yang berlangsung mengacu pada satu rangkaian pertanyaan terbuka. Metode ini memungkinkan pertanyaan baru muncul karena jawaban yang diberikan oleh narasumber sehingga selama sesi berlangsung penggalian informasi dapat dilakukan lebih mendalam. Lain halnya dengan interview terstruktur, pewawancara berpedoman pada pertanyaan lengkap dan terperinci, layaknya sebuah kuesioner. Selama sesi wawancara berlangsung, pertanyaan baru tidak dapat ditambahkan sehingga penggalian informasi mungkin sangat terbatas.

Jenis wawancara yang digunakan peneliti adalah wawancara semi berstruktur. Instrumen wawancara digunakan dalam penelitian kualitatif karena dapat mengungkap informasi lintas waktu, yaitu berkaitan dengan masa lampau, masa sekarang, dan masa yang akan datang. Dan data yang dihasilkan dari wawancara bersifat terbuka, menyeluruh, dan tidak terbatas, sehingga mampu membentuk informasi yang utuh dan menyeluruh dalam mengungkap penelitian kualitatif (Ulfatin, 2014).

\section{Instrumen Angket}

Kuesioner merupakan teknik pengumpulan data yang dilakukan dengan cara memberi seperangkat pernyataan tertulis kepada responden untuk di jawabnya. Kuesioner yang digunakan oleh peneliti sebagai instrumen penelitian, metode yang digunakan adalah dengan kuesioner tertutup.

Instrument kuesioner harus diukur validitas dan reabilitas datanya sehingga penelitian tersebut menghasilkan data yang valid dan reliable. Instrumen yang valid berarti instrument tersebut dapat dipergunakan untuk mengukur apa yang seharusnya diukur, sedangkan instrument yang reliable adalah instrumen yang apabila digunakan beberapa kali untuk mengukur objek yang sama akan menghasilkan data yang sama pula. Instrumen yang digunakan untuk mengukur variabel penelitian ini dengan menggunakan skala likert 5 poin. Jawaban responden berupa pilihan dari lima 
alternatif yang ada, yaitu :

1. SS : Sangat Setuju

2. S : Setuju

3. $\mathrm{N}$ : Netral

4. TS : TidakSetuju

5. STS : Sangat Tidak Setuju

Masing-masing jawaban memiliki nilai sebagai berikut :

1. SS : 5

2. $\mathrm{S}: 4$

3. $\mathrm{N}: 3$

4. TS : 2

5. STS : 1

Validitas berarti kesucian alat ukur dengan apa yang hendak diukur, artinya alat ukur yang digunakan dalam pengukuran dapat digunakan untuk mengukur apa yang hendak diukur. Jadi validitas adalah seberapa jauh alat dapat mengukur hal atau objek yang ingin diukur. Reabilitas artinya memiliki sifat yang dapat dipercaya. Suatu alat ukur dikatakan memiliki reabilitas apabila dipergunakan berkali-kali oleh peneliti yang sama atau oleh peneliti lain akan tetapi memberikan hasil yang sama. Jadi reabilitas adalah seberapa jauh konsistensi alat ukur untuk dapat memberikan hasil yang sama dalam mengukur dalam hal dan objek yang sama.

\section{HASIL PENELITIAN}

Penelitian ini telah didapatkan beberapa informasi yang dihasilkan dari proses pengumpulan data melalui beberapa teknik yang dilakukan baik melalui proses wawancara, studi dokumen, dan kuisioner yang diperoleh dari guru dan siswa dengan memanfaatkan akun belajar.id kemdikbud dalam proses pembelajaran serta wawancara orang tua tentang pelajaran bahasa Indonesia dan pemanfaatan akun belajar.id kemdikbud dalam pembelajaran daring.

Wawancara dilaksanakan dengan menggunakan teknik wawancara terstruktur terhadap 1 orang guru kelas 6, 10 siswa kelas 6, dan 5 orang tua siswa kelas 6 sebagai narasumber kunci yang dilakukan secara daring menggunakan lembar wawancara yang dikirim melalui aplikasi whatsapp.

Wawancara dengan narasumber guru kelas 6 inisial NAS dilaksanakan pada hari Senin, 4 Oktober 2021; narasumber dengan inisial RBS, GFS, RPW, ZADP, NLK, SAA, YF, RRK, RAS, RAW dilaksanakan secara serempak melalui aplikasi whasapp pada hari Rabu, 20 Oktober 2021 sedangkan narasumber dengan inisial RP, TA, SRS, NP, AS dilaksanakan secara serempak melalui aplikasi whatsapp pada hari Minggu, 14 November 2021.

2.1. Hasil Wawancara dengan Guru

Data yang tidak terungkap melalui wawancara, dilengkapi dengan data hasil observasi langsung secara partisipatif yang dilakukan rentang waktu pada bulan September sampai November 2021. Untuk memperkuat substansi data hasil wawancara dan observasi, maka dilakukanlah penelusuran terhadap dokumen dan arsip yang ada. Semua data hasil penelitian ini diuraikan berdasarkan fokus pertanyaan penelitian sebagai berikut:

a. Rencana Pelaksanaan Pemebelajaran (RPP)

Rencana Pelaksanaan Pembelajaran (RPP) adalah rencana kegiatan pembelajaran untuk satu pertemuan atau lebih. RPP dikembangkan secara rinci dari suatu materi pokok atau tema tertentu yang mengacu pada silabus untuk mengarahkan kegiatan pembelajaran siswa dalam upaya mencapai Kompetensi Dasar (KD). Setiap pendidik pada satuan pendidikan berkewajiban menyusun RPP secara lengkap dan sistematis agar pembelajaran berlangsung secara interaktif, isnpiratif, menyenangkan, menantang, efisien, memotivasi siswa untuk berpartisipasi aktif, serta memberikan ruang yang cukup bagai prakarsa, kreativitas, dan kemandirian sesuai dengan bakat, minat, dan perkembangan fisik serta psikologis siswa. RPP disusun berdasarkan KD atau subtema yang dilaksanakan dalam satu kali pertemuan atau 
lebih".

Komponen RPP terdiri atas: 1) Identitas sekolah yaitu nama satuan pendidikan, 2) Identitas mata pelajaran atau tema/sub tema, 3) Kelas/semester, 4) Materi pokok, 5) Alokasi waktu ditentukan sesuai dengan keperluan untuk pencapaian KD dan beban belajar dengan mempertimbangkan jumlah jam pelajaran yang tersedia dalam silabus dan KD yang harus dicapai, 6) Kompetensi Inti (KI), merupakan gambaran secara kategorial mengenai kompetensi dalam aspek sikap, pengetahuan, dan keterampilan yang harus dipelajari siswa, 7) Kompetensi dasar dan indikator pencapaian kompetensi, a) Kompetensi Dasar: merupakan kemampuan spesifik yang mencakup sikap, pengetahuan, dan keterampilan yang terkait muatan atau mata pelajaran, b) Indikator pencapaian merupakan penanda pencapaian kompetensi dasar yang ditandai oleh perubahan perilaku yang dapat diukur yang mencakup sikap, pengetahuan, dan keterampilan, c) Indikator dikembangkan sesuai dengan karakteristik siswa, satuan pendidikan, dan potensi daerah. Indikator digunakan sebagai dasar untuk menyusun alat penilaian. Indikator harus dapat menggunakan kata kerja operasional yang sesuai,

8) Tujuan pembelajaran yang dirumuskan berdasarkan KD, dengan menggunakan kata kerja operasional yang dapat diamati dan diukur, yang mencakup sikap, pengetahuan, dan ketrampilan, 9) Materi pembelajaran adalah rincian dari materi pokok yang memuat fakta, konsep, prinsip, dan prosedur yang relevan, dan ditulis dalam bentuk butir-butir sesuai dengan rumusan indikator ketercapaian kompetensi, 10) Metode pembelajaran merupakan rincian dari kegiatan pembelajaran, digunakan oleh pendidik untuk mewujudkan suasana belajar dan proses pembelajaran agar peserta didik mencapai KD yang disesuaikan dengan karakteristik peserta didik dan KD yang akan dicapai, 11) Media, alat, dan sumber pembelajaran, 12) Langkah-langkah Kegiatan Pembelajaran, mencakup kegiatan pendahuluan, inti, dan penutup, 13) Penilaian, berisi jenis/teknik penilaian, bentuk istrument dan pedoman penskoran.

Peneliti melakukan teknik wawancara dan dokumentasi untuk memperoleh data dari narasumber tentang penyusunan Rencana Pelaksanaan pembelajaran (RPP) dan pengembangannya. Narasumber NAS menggatakan bahwa:

"Rencana Pelaksanaan Pembelajaran (RPP) disusun guru sebelum melaksanakan pembelajaran dengan tujuan untuk membantu dalam mengajar agar sesuai dengan Kompetensi Dasar pada setiap pertemuan. RPP berisi pengaturan yang berkenaan dengan perkiraan atau proyeksi tentang apa yang akan dilakukan pada saat kegiatan belajar mengajar berlangsug, kemungkinan pelaksanaan pembelajaran sesuai dengan rencana pelaksanaan pembelajaran yang telah direncanakan ataupun tidak karena proses pembelajaran bersifat kondisional. Apabila perencanaan disusun secara matang maka proses dan hasil pembelajaran tidak akan jauh dari perkiraan".

\section{b. Pelaksanaan Pembelajaran secara Daring}

Kegiatan pembelajaran merupakan proses pendidikan yang harus dipersiapkan terlebih dahulu supaya pembelajaran dapat terlaksana sesuai dengan yang diharapkan, apalagi pembelajaran dilaksanakan secara daring membutuhkan persiapan atau perencanaan yang matang. Hasil wawancara dengan NAS yang mengatakan bahwa :

"Pembelajaran daring membutuhkan persiapan antara lain guru harus dapat membuat Rencana Pelaksanaan Pembelajaran (RPP) daring, guru mampu memanfaatkan media teknologi, guru juga harus mendorong orang tua agar ikut aktif dalam membantu kebutuhan anak dalam proses pembelajaran, guru menyampaikan rangkuman materi, guru menasihati siswa untuk menjadi anak-anak yang lebih tangguh karena pembelajaran daring membutuhkan konsentrasi belajar. Guru juga mempu memberikan solusi apabila ada kendala jaringan online supaya pembelajaran dapat terlaksanan dengan lancar".

Pembelajaran yang dilaksanakan secara daring membutuhkan pengetahuan tambahan tentang google workspace for education. Hasil wawancara dengan narasumber NAS tentang pernah atau tidaknya mengikuti pelatihan atau sosialisasi mengenai google workspace for education adalah sebagai berikut:

"Pernah, ada dua pelatihan yang saya ikuti antara lain Pelatihan Google Workspace For Education Terintegrasi Portal Rumah Belajar dan Pelatihan Mengajar di mana saja dengan Akun Pembelajaran oleh Google Master Trainer - GTK Kemdikbud. Kedua pelatihan tersebut membekali guru sebagai pengajar di 
masa pandemi Covid 19 karena guru dapat memanfaatkan workspace yang ada untuk kelancaran pembelajaran secara daring".

Pembelajaran yang dilaksanakan secara daring mengharuskan guru mempunyai akun yang dapat digunakan untuk mengakses semua platform yang disediakan oleh google workspace form education yaitu akun belajar.id kemdikbud. Hasil wawancara dengan narasumber NAS tentang kepemilikan akun belajar.id kemdikbud adalah sebagai berikut:

"Iya, guru mendapatkan akun pembelajaran yang bertanda belajar.id dan kata sandi (password) yang dapat digunakan untuk mengakses berbagai aplikasi pembelajaran secara gratis. Akun belajar.id Kemdikbud dapat mengakses semua platform Kemendikbudristek dan dapat menyimpan data secara daring dengan lebih aman dengan kapasitas penyimpanan tak terbatas".

Data yang diperoleh dari teknik pengumpulan data tentang pemanfaatan akun belajar.id kemdikbud juga diperoleh dari dokumentasi berupa Rencana Pelaksanaan Pembelajaran yang memuat pemanfaatan akun belajar.id kemdikbud.

Berdasarkan hasil wawancara dan dokumentasi diambil kesimpulan bahwa guru dengan inisial NAS yang mengajar kelas 6 di SDN Margomulyo 1 Ngawi dalam melaksanakan pembelajaran daring dengan memanfaatkan akun belajar.id kemdikbud terlebih dahulu merencanakan pembelajaran daring dengan menyusun Rencana Pelaksanaan Pembelajara (RPP) yang mengacu pada silabus. Guru dengan inisial NAS juga memiliki akun belajar.id kemdikbud dan sudah diaktivasi sehingga dapat digunakan dalam pembelajaran daring untuk mengakses platform kemendikbudristek.

c. Keefektifan pembelajaran dengan Memanfaatan Aku Belajar.id Kemdikbud

Pandemi covid 19 mengharuskan guru melaksanakan pembelajaran secara daring sehingga siswa tetap dalam pantauan guru selama melaksanakan pembelajaran. Pemanfaatan akun belajar.id kemdikbud menjadikan pembelajaran bahasa Indomesia secara daring dapat terlaksana dengan efektif karena guru dapat menyampaikan materi pembelajaran secara tatap muka melalui google meet sehingga anak-anak tidak perlu lagi hadir ke sekolah untuk menerima materi pelajaran dari guru. Pelaksanaan ulangan harian juga bisa dilaksanakan dari rumah dengan memanfaatkan google form. Hasil wawancara dengan narasumber NAS tentang keefektifan akun belakar.id kemdikbud terhadap pelaksanaan pembelajaran secara daring selama pandemi covid 19 di kelas yang diampunya adalah sebagai berikut:

"Pembelajaran daring dengan menggunakan akun belajar.id sangat memudahkan guru karena semua workspace for education yang tersedia dapat diakses secara gratis dan memiliki kapasitas penyimpanan tak terbatas. Workspace yang biasa digunakan adalah google meet untuk pelaksanaan pembelajaran, google classroom untuk penyampaian materi dan pengiriman tugas, google drive untuk penyimpanan data absensi, dan pelaksanaan ulangan harian. Dengan akun belajar.id kemdikbud pembelajaran bahasa Indonesia dapat dilaksanakan dengan efektif karena guru dan siswa tidak perlu bertemu secara langsung di sekolah namun dapat bertemu di kelas maya menggunakan google meet dan melaksanakan ulangan harian dengan google form".

d. Kendala Pembelajaran Daring dan Penyelesaiannya

Pembelajaran secara daring dengan memanfaatkan akun belajar.id kemdikbud memang sangat membantu guru dan siswa. Namun ada beberapa kendala yang dihadapi siswa dalam memanfaatkan akun belajar.id kemdikbud seperti hasil wawancara yang disampaikannya berikut ini:

"Penerapan akun belajar.id Kemdikbud bukan berarti tanpa kendala. Beberapa masalah yang dihadapi dalam penerapan akuin belajar.id Kemdikbud diantaranya kurangnya kemampuan dalam memahami cara memasang akun belajar.id di handphone atau lap top. Selain itu, dibenak guru dan siswa akan adanya kerepotan bila harus mengganti akun yang lama. Selain itu kendala yang lainnya adalah gagal login bagi siswa yang disebabkan kurangnya sosialisasi secara tatap muka atau virtual oleh admin sekolah. Kendala tersebut dapat diatasi setelah adanya sosialisasi oleh admin sekolah".

Pemanfaatan akun belajar.id kemdikbud sangatlah membantu keberhasilan selama pembelajaran daring. Kelebihan pemanfaatan akun akun belajar.id kemdikbud seperti yang disampaikan oleh narasumber inisial NAS berikut ini: 
"Kelebihan akun belajar.id Kemdikbud antara lain merupakan flatform yang dipakai secara gratis yang diberikan oleh Kemdikbud dan akunnya pun diberikan kepada guru-guru dan siswa sehingga memberi kemudahan kepada guru untuk memakai aplikasi-aplikasi yang ada di google bila telah mengaktifkan dan menggunakan akun@belajar.id. Memudahkan space penyimpanan data bagi guru dan siswa dengan kapasitas penyimpanan tak terbatas. Selain itu juga memudahkan dalam kegiatan meet karena di classroom sudah ada dalam setiap kelas yang dibuat, memudahkan bagi siswa dan guru".

Selain kelebihan yang disampaikan narasumber dengan inisal NAS di atas, pemanfaatam akun belajar.id kemdikbud juga ada kendala. Kendala tersebut harus mendapatkan solusi. Narasumber inisial NAS mengatakan bahwa :

"Pembelajaran secara daring merupakan solusi dalam melaksanakan pembelajaran selama pandemi Covid19. Adapun kendala utama dalam pembelajaran daring adalah keterjangkauan jaringan internet yang disebabkan lokasi rumah siswa yang jauh sehingga tidak bisa dijangkau jaringan internet. Namun kendala tersebut tidak dialami oleh siswa kelas 6 SDN Margomulyo 1 Ngawi karena domisili mereka berada dalam kota. Kendala berikutnya adalah ketersediaan kuota siswa yang minim. Hal ini dapat diatasi dengan diaktifkannya akun belajar.id Kemdikbud sehingga pembelajaran dapat terlaksana dengan lancar karena siswa dapat mengakses workspace secara gratis untuk pembelajaran".

Berdasarkan hasil wawancara dan dokumentasi diambil kesimpulan bahwa guru dengan inisial NAS yang mengajar kelas 6 di SDN Margomulyo 1 Ngawi dalam pelaksanaan pembelajaran secara daring dengan memanfaatkan akun belajar.id kemdikbud. Pemanfaatan akun belajar.id kemdikbud memiliki banyak kelebihan sehingga sangat membantu guru dalam pelaksanaan pembelajaran daring. Meskipun banyak kelebihan namun ada juga kendala namun kendala tersebut dapat teratasi sehingga pembelajaran daring selama pandemi covid 19 dapat terlaksana dengan lancar.

Keberhasilan proses pembelajaran selain dipengaruhi oleh metode pembelajaran, alat atau perangkat yang digunakan selama pembelajaran daring juga sangat penting. Jenis alat yang digunakan narasumber inisial NAS dalam proses pembelajaran daring adalah seperti hasil wawancara berikut ini:

"Alat yang digunakan demi kelancaran pembelajaran secara daring antara lain: (1) Lap Top, Lap top menjadi pilihan yang tepat selama pembelajaran daring karena bentuknya yang sederhana tidak memerlukan banyak tempat dan mudah untuk dipindahkan dari satu lokasi ke lokasi yang lain sehingga memudahkan untuk melaksanakan pembelajaran daring dimana saja. Lap top cukup fleksibel karena dapat digunakan dalam waktu berjam-jam tanpa akses ke stop kontak daya. Jadi, tidak perlu merasa khawatir jika terjadi pemadaman listrik di rumah".

"(2) Gadget, Gadget merupakan salah satu bagian dari perkembangan teknologi yang selalu menghadirkan perkembangan terbaru yang dapat membantu berbagai kegiatan manusia menjadi lebih mudah. Kehadiran gadget di zaman yang serba canggih ini sudah menjadi kebutuhan utama. Pada masa pandemi, gadget digunakan untuk menunjang proses pembelajaran sehingga sangat membantu interasksi antara guru dan siswa melalui whatssapp group kelas".

“(3) Earphone, Pembelajaran jarak jauh secara virtual dengan memanfaatkan IPTEK yang semakin maju, guru selalu menggunakan earphone ketika pembelajaran melalui google meet agar menghasilkan kualitas suara yang jernih serta mencegah masuknya suara bising-bising dari lingkungan sekitar sehingga dapatlebih folus dalam proses pembelajaran".

Keberhasilan dalam pelaksanaan pembelajaran daring dengan memanfaatkan akun belajar.id kemdikbud salah satunya ditentukan juga oleh keberhasilan dalam penilaian siswa. Meskipun pembelajaran dilaksanakan secara daring, ada beberapa jenis penilaian yang digunakan guru selama pembelajaran dengan memanfaatkan akun belajar.id kemdikbud seperti yang disampaikan narasumber inisial NAS berikut ini:

"Penilaian pembelajaran dilaksanakan untuk mengetahui ketuntasan belajar siswa pada setiap kompetensi dasar yang telah dilaksanakan. Penilaian yang dilaksanakan selama pembelajaran daring antara lain penilaian sikap yang meliputi disiplin, tanggung jawab, dan komunikatif. Selanjutnya penilaian harian yang dilaksanakan di akhir pembelajaran di setiap sub pokok bahasan”. 
Penilaian guru tidak terbatas pada pemberian penilaian harian saja, namun juga penugasan rutin setiap hari sebagai tindak lanjut dari materi yang sudah disampaikan sesuai dengan hasil wawancara dengan guru dengan inisial NAS berikut ini:

"Rutin, tugas diberikan setiap hari dengan pembahasan pada pertemuan berikutnya. Pemberian tugas setiap hari dengan tujuan untuk mempercepat pemahaman siswa tentang materi pembelajaran. Dengan mengerjakan tugas dari guru untuk memperbanyak intensitas latihan sehingga materi yang disampaikan segera dikuasai"

.Pembelajaran akan lebih bermakna apabila dilaksakan tindak lanjut dari hasil pembelajaran yang sudah dilaksanakan. Berikut ini hasil wawancara dengan narasumber berinisial NAS tentang tindak lanjut pembelajaran:

"Tindak lanjut hasil pembelajaran dilaksanakan setelah dilaksanakan penilaian harian. Ketuntasan belajar didasarkan pada KKM kompetensi dasar yang dicapai siswa. Hasil dari penilaia harian dianalisis dan akan diketahui siswa yang sudah tuntas dan siswa yang belum tuntas. Tindak lanjut dari hasil penilaian harian bagi siswa yang belum tuntas ketercapaian kompetensi dasar adalah remidial dan bagi siswa yang sudah tuntas ketercapaian kompetensi dasar adalah pengayaan".

Berdasarkan hasil wawancara dan dokumentasi diambil kesimpulan bahwa guru dengan inisial NAS yang mengajar kelas 6 di SDN Margomulyo 1 Ngawi dalam melaksanakan tindak lanjut pembelajaran adalah dengan melaksanakan penilaian dengan memanfaatkan akun belajar.id kemdikbud. Guru dengan inisial NAS melaksanakan penilaian sikap dan penilaian ketuntasan belajar di setiap akhir sub pokok bahasan. Selain itu, guru juga memberikan tugas secara rutin kepada siswa dan dibahas secara daring pada pertemuan berikutnya. Guru juga menganalisis hasil penilaian harian untuk dilakukan tindak lanjut hasil pembelajaran.

Hasil wawancara dengan siswa kelas 6 tentang pelaksanaan pembelajaran Bahasa Indonesia selama pandemi covid 19 dilaksanakan dengan memanfaatkan akun belajar.id kemdikbud dengan memanfaatkan workspace pada akun tersebut antara lain google meet dan google form seperti yang disampaikan narasumber dengan inisial RBS berikut ini:

"Iya, pembelajaran bahasa Indonesia selama pandemi covid 19 memanfaatkan akun belajar.id kemdikbud. Penyampaian materi pembelajaran memanfaatkan google meet sehingga siswa dan guru dapat berinteraksi secara virtual".

Kepemilikan akun belajar.id kemdikbud serta aktivasi dari akun tersebut merupakan hal yang sangat penting untuk bisa mengakses fitur-fitur workspace for education secara gratis. Namun ada beberapa siswa yang akun belajar.id kemdikbudnya tidak bisa digunakan karena gagal aktivasi. Hal tersebut dialami oleh narasumber berinisial RBS dan dapat diatasi seperti yang disampaikan berikut ini:

"Saya memiliki akun belajar.id kemdikbud dan sudah saya aktivasi" namun tidak bisa saya gunakan. Saya lapor kepada guru. Akun dimasukkan data laporan ke admin pusat untuk mendapatkan akun baru atau direset ulang sehingga dapat digunakan. Selama menunggu akun saya yang baru, sementara waktu, untuk mengikuti pembelajaran, saya menggunakan akun pribadi untuk bisa login google meet, classroom, dan membuka link soal"

Narasumber berinisial RBS mengatakan bahwa setelah akun belajar.id kemdikbud miliknya bisa diaktivasi dan login, pembelajaran selanjutnya sudah tidak menggunakan akun pribadi lagi. Narasumber RBS juga mengatakan tentang keefektifan pembelajaran dengan memanfaatkan akun belajar.id kemdikbud sebagai beriktu:

"Pembelajaran selama pandemi covid 19 menjadi efektif dengan memanfaatkan akun belajar id.kemdikbud karena penyampaian materi oleh guru melalui google meet dapat mendekatkan jarak antara guru di sekolah dan siswa di rumah. Selain itu pelaksanaan ulangan harian juga lebih mudah menggunakan google form. Siswa tidak perlu datang ke sekolah untuk mengerjakannya".

Pembelajaran selama pandemi covid 19 dapat dilaksanakan secara daring. Guru dan siswa bisa belajar secara tatap muka melalui google meet, namun tujuan pendidikan tidak cukup dengan menyampaikan materi saja. Teladan dan pendidikan karakter harus ditanamkan sejak dini. Harapannya pandemi covid 19 ini segera berakhir dan pembelajaran dapat terlaksana secara tatap muka di sekolah seperti yang disamapaikan narasumber dengan inisial RBS berikut ini: 
"Harapan kami sebagai siswa, pembelajaran dapat segera dilaksanakan secara tatap muka di sekolah. Selain dapat bertemu langsung dengan guru, juga dapat bermain dengan teman-teman di sekolah."

Narasumber berikutnya adalah siswa kelas 6 dengan inisial GFS. Kesukaannya terhadap pembelajaran Bahasa Indonesia tidak mengendorkan semangatnya untuk mengikuti pembelajaran bahasa Indonesia meskipun dilaksanakan secara daring selama pandemi covid 19 dengan memanfaatkan akun belajar.id kemdikbud seperti yang disampaikan narasumber dengan inisial GS berikut ini:

"Saya sangat suka dengan pelajaran bahasa Indonesia. Bersyukur selama pandemi Covid 19 pembelajaran bahasa Indonesia dapat dilaksanakan dengan memanfaatkan akun belajar.id kemdikbud."

Fitur-fitur workspace for education dapat diakses secara gratis dengan akun belajar.id kemdikbud. Kepemilikan dan keberhasilan aktivasi dari akun tersebut merupakan hal yang sangat penting. Berbeda dengan siswa dengan inisial RBS, siswa dengan inisial GFS ini memiliki akun belajar.id yang sudah diaktivasi dan dapat digunakan seperti yang disampaikan berikut ini:

"Akun belajar.id kemdikbud saya sudah berhasil saya aktifkan sehingga saya dapat menggunakan akun tersebut untuk mengikuti pembelajaran secara daring".

Narasumber GFS juga memberikan pendapatnya tentang keefektifan pembelajaran dengan memanfaatkan akun belajar.id kemdikbud sebagai berikt:

"Pembelajaran selama pandemi covid 19 menjadi efektif dengan memanfaatkan akun belajar id.kemdikbud karena penyampaian materi oleh guru melalui google meet dapat mendekatkan jarak antara guru di sekolah dan siswa di rumah. Selain itu pelaksanaan ulangan harian juga lebih mudah menggunakan google form. Siswa tidak perlu datang ke sekolah untuk mengerjakannya".

Narasumber berikutnya adalah siswa kelas 6 dengan inisial RPW. Pembelajaran Bahasa Indonesia dilaksanakan secara daring selama pandemi covid 19 dengan memanfaatkan akun belajar.id kemdikbud. "Pembelajaran bahasa Indonesia dilaksanakan secara daring dengan memanfaatkan akun belajar.id kemdikbud sehingga siswa dapat belajar dengan guru dengan lancar.".

Fitur-fitur workspace for education dapat diakses secara gratis dengan akun belajar.id kemdikbud. Kepemilikan dan keberhasilan aktivasi dari akun tersebut merupakan hal yang sangata penting. Siswa dengan inisial RPW sama dengan siswa dengan inisial GFS yaitu memiliki akun belajar.id yang sudah diaktivasi dan dapat digunakan seperti yang disampaikan berikut ini:

"Saya sudah berhasil mengaktifkan akun belajar.id kemdikbud sehingga dapat saya gunakan untuk pembelajaran secara daring selama pandemi Covid-19".

Narasumber RPW memberikan pendapatnya tentang keefektifan pembelajaran dengan memanfaatkan akun belajar.id kemdikbud sebagai berikut:

"Pembelajaran selama pandemi covid 19 menjadi efektif dengan memanfaatkan akun belajar id.kemdikbud karena penyampaian materi oleh guru melalui google meet dapat mendekatkan jarak antara guru di sekolah dan siswa di rumah. Selain itu pelaksanaan ulangan harian juga lebih mudah menggunakan google form. Siswa tidak perlu datang ke sekolah untuk mengerjakannya".

Narasumber RPW tidak mengalami kendala dengan akun belajar.id kemdikbud miliknya seperti yang disampaikan dari hasil wawancara sebagai berikut :

"Akun belajar.id kemdikbud milik saya sudah bisa saya aktivasi dan saya bisa mengikuti pembelajaran secara daring dengan lancar".

Narasumber berikutnya adalah siswa dengan inisial ZADP. Pembelajaran Bahasa Indonesia dilaksanakan secara daring selama pandemi covid 19 dengan memanfaatkan akun belajar.id kemdikbud. seperti yang disampaikan berikut ini:

"Saya suka dengan pelajaran bahasa Indonesia. Kebetulan ayah saya seorang budayawan Kota Ngawi. Membaca buku adalah hobi kami. Saya sering mengikuti berbagai perlombaan kebahasaan anatara lain membaca puisi, bercerita, dan pidato. Saya sering mendapatkan piala kejuaraan. Selama pandemi covid 19, pembelajaran bahasa Indonesia dilaksanakan secara daring dengan memanfaatkan akun belajar.id kemdikbud.".

Narasumber ZADP memberikan pendapatnya tentang keefektifan pembelajaran dengan memanfaatkan akun belajar.id kemdikbud sebagai berikut: 
"Pembelajaran selama pandemi covid 19 menjadi efektif dengan memanfaatkan akun belajar id.kemdikbud karena penyampaian materi oleh guru melalui google meet dapat mendekatkan jarak antara guru di sekolah dan siswa di rumah. Selain itu pelaksanaan ulangan harian juga lebih mudah menggunakan google form. Siswa tidak perlu datang ke sekolah untuk mengerjakannya".

Fitur-fitur workspace for education dapat diakses secara gratis dengan akun belajar.id kemdikbud. Kepemilikan dan keberhasilan aktivasi dari akun tersebut merupakan hal yang sangata penting. Siswa dengan inisial ZADP memiliki akun belajar.id yang sudah diaktivasi dan dapat digunakan seperti yang disampaikan berikut ini:

"Iya, saya sudah memiliki akun belajar.id kemdikbud dan sudah berhasil saya aktivasi sehingga bisa saya gunakan untuk memperlancar pembelajaran bahasa Indonesia”.

Pembelajaran selama pandemi covid 19 dapat dilaksanakan secara daring. Guru dan siswa bisa belajar secara tatap muka melalui google meet, namun tujuan pendidikan tidak cukup dengan menyampaikan materi saja. Teladan dan pendidikan karakter harus ditanamkan sejak dini. Harapannya pandemi covid 19 ini segera berakhir dan pembelajaran dapat terlaksana secara tatap muka di sekolah seperti yang disamapaikan narasumber dengan inisial ZADP berikut ini:

"Pembelajaran tatap muka selama pandemi covid 19 tidaklah mungkin sehingga pembelajaran dilaksanakan secara daring. Meskipun dapat terlaksana namun tidak maksimal. Mudah-mudahan pembelajaran dapat segera dilaksanakan di sekolah secara tatap muka."

Narasumber berikutnya adalah siswa dengan inisial NLK. Pembelajaran Bahasa Indonesia dilaksanakan secara daring selama pandemi covid 19 dengan memanfaatkan akun belajar.id kemdikbud seperti yang disampaikan berikut ini:

"Saya suka dengan pelajaran bahasa Indonesia. Selama pandemi covid 19 pembelajaran dilaksanakan dengan memanfaatkan akun belajar.id kemdikbud".

Narasumber NLK memberikan pendapatnya tentang keefektifan pembelajaran dengan memanfaatkan akun belajar.id kemdikbud sebagai berikt:

"Pembelajaran selama pandemi covid 19 menjadi efektif dengan memanfaatkan akun belajar id.kemdikbud karena penyampaian materi oleh guru melalui google meet dapat mendekatkan jarak antara guru di sekolah dan siswa di rumah. Selain itu pelaksanaan ulangan harian juga lebih mudah menggunakan google form. Siswa tidak perlu datang ke sekolah untuk mengerjakannya".

Fitur-fitur workspace for education dapat diakses secara gratis dengan akun belajar.id kemdikbud. Kepemilikan dan keberhasilan aktivasi dari akun tersebut merupakan hal yang sangata penting. Siswa dengan inisial NLK memiliki akun belajar.id yang sudah diaktivasi dan dapat digunakan seperti yang disampaikan berikut ini:

"Saya sudah memiliki akun belajar.id kemdikbud dan Alhamdulillah sudah berhasil saya aktivasi. Sudah saya gunakan untuk mengikuti pembelajaran bahasa Indonesia".

Narasumber NLK tidak mengalami kendala dalam mengikuti pembelajaran bahasa Indonesia dengan akun belajar.id kemdikbud, namun kendala yang dihadapinya adalah NLK belum memiliki handphone sendiri untuk mengukuti pembelajaran daring sehingga harus memasang akun tersebut pada handphone orang tuanya seperti yang disampaikan berikut ini:

"Saya belum memiliki handphone android sendiri, namun pembelajaran bahasa Indonesia dapat saya ikuti dengan lancar dengan menggunakan akun belajar.id kemdikbud yang saya pasang di handphone milik orang tua saya sehingga saya masih tetap bisa melaksanakan pembelajaran bahasa Indonesia secara daring selama pandemi covid 19".

Narasumber berikutnya adalah siswa dengan inisial SAA. Pembelajaran Bahasa Indonesia dilaksanakan secara daring selama pandemi covid 19 dengan memanfaatkan akun belajar.id kemdikbud. seperti yang disampaikan berikut ini:

"Pelajaran bahasa Indonesia dilaksanakan dengan memandaaftkan akun belajar.id kemdikbud sehingga tidak mengalami masalah".

Narasumber SAA memberikan pendapatnya tentang keefektifan pembelajaran dengan memanfaatkan akun belajar.id kemdikbud sebagai berikt: 
"Pembelajaran selama pandemi covid 19 menjadi efektif dengan memanfaatkan akun belajar id.kemdikbud karena penyampaian materi oleh guru melalui google meet dapat mendekatkan jarak antara guru di sekolah dan siswa di rumah. Selain itu pelaksanaan ulangan harian juga lebih mudah menggunakan google form. Siswa tidak perlu datang ke sekolah untuk mengerjakannya”.

Fitur-fitur workspace for education dapat diakses secara gratis dengan akun belajar.id kemdikbud. Kepemilikan dan keberhasilan aktivasi dari akun tersebut merupakan hal yang sangata penting. Siswa dengan inisial SAA memiliki akun belajar.id yang sudah diaktivasi dan dapat digunakan seperti yang disampaikan berikut ini:

"Iya, saya sudah memiliki akun belajar.id kemdikbud dan sudah berhasil saya aktivasi sehingga bisa saya gunakan untuk pembelajaran bahasa Indonesia".

Narasumber dengan inisial SAA memiliki handphone android sendiri untuk menunjang pembelajaran daring selama pandemi covid 19 dengan memanfaatkan akun belejar.id kemdikbud seperti yang disampaikan berikut ini:

"Saya memiliki handphone android sendiri bukan milik orang tua, pembelajaran bahasa Indonesia dapat saya ikuti dengan lancar menggunakan akun belajar.id kemdikbud".

Hasil wawancara tentang kelancaran pembelajaran bahasa Indonsia dengan memanfaatkan akun belajar.id kemdikbud seperti yang disampaikan narasumber dengan inisial SAA sebagai beriktu:

"Saya dapat mengikuti pembelajaran bahasa Indonesia menggunakan akun akun belajar.id kemdikbud dengan lancar".

Penyampaian materi secara daring dengan memanfaatkan akun belajar.id kemdikbud tetaplah harus bisa menfasilitasi proses belajar bagi semua siswa secara merata. Pemahaman siswa terhadap materi yang disampaikan guru secara daring tetap yang utama. Narasumber dengan inisial SAA menyampaikan pendapatnya sebagai berikut:

"Materi bahasa Indonesia disampaikan guru menggunakan akun belajar.id kemdikbud melalui google meet".

Narasumber berikutnya adalah siswa dengan inisial YF. Pembelajaran Bahasa Indonesia dilaksanakan secara daring selama pandemi covid 19 dengan memanfaatkan akun belajar.id kemdikbud. Narasumber dengan inisial YF menyukai pelajaran bahasa Indonesia meskipun tidak begitu bisa menyampaikan pendapatnya dengan bahasa yang baik seperti yang disampaikan berikut ini:

"Saya menyukai pelajaran bahasa Indonesia namun saya kurang bisa menyampaikan pendapat dengan bahasa yang baik. Selama pandemi covid 19, pembelajaran dapat dilaksanakan dengan memenfaatkan akun belajar.id kemdikbud".

Narasumber YF memberikan pendapatnya tentang keefektifan pembelajaran dengan memanfaatkan akun belajar.id kemdikbud sebagai berikut:

"Pembelajaran selama pandemi covid 19 menjadi efektif dengan memanfaatkan akun belajar id.kemdikbud karena penyampaian materi oleh guru melalui google meet dapat mendekatkan jarak antara guru di sekolah dan siswa di rumah. Selain itu pelaksanaan ulangan harian juga lebih mudah menggunakan google form. Siswa tidak perlu datang ke sekolah untuk mengerjakannya".

Fitur-fitur workspace for education dapat diakses secara gratis dengan akun belajar.id kemdikbud. Kepemilikan dan keberhasilan aktivasi dari akun tersebut merupakan hal yang sangata penting. Siswa dengan inisial YF memiliki akun belajar.id yang sudah diaktivasi dan dapat digunakan seperti yang disampaikan berikut ini:

"Iya, saya memiliki akun belajar.id kemdikbud dan berhasil saya aktivasi sehingga bisa saya gunakan untuk pembelajaran bahasa Indonesia".

Narasumber dengan inisial YF memiliki handphone android sendiri untuk menunjang pembelajaran daring selama pandemi covid 19 dengan memanfaatkan akun belejar.id kemdikbud seperti yang disampaikan berikut ini:

"Saya memiliki handphone android sendiri, dengan menggunakan akun belajar.id kemdikbud pembelajaran bahasa Indonesia dapat saya ikuti dengan lancar".

Hasil wawancara tentang kelancaran pembelajaran bahasa Indonsia dengan memanfaatkan akun belajar.id kemdikbud seperti yang disampaikan narasumber dengan inisial YF sebagai beriktu: 
"Pembelajaran dapat saya ikuti dengan lancar dengan menggunakan akun akun belajar.id kemdikbud".

Narasumber berikutnya adalah siswa dengan inisial RRK. Pembelajaran Bahasa Indonesia dilaksanakan secara daring selama pandemi covid 19 dengan memanfaatkan akun belajar.id kemdikbud. seperti yang disampaikan berikut ini:

"Saya menyukai pelajaran bahasa Indonesia. Materi yang saya suka mengarang. Pembelajaran bahasa Indonesia dapat terlaksana dengan lancar karena selama pandemi covid 19 guru dan siswa memiliki akun belajar.id kemdikbud yang dapat mengakses semua workspace for education secara gratis".

Narasumber RRK memberikan pendapatnya tentang keefektifan pembelajaran dengan memanfaatkan akun belajar.id kemdikbud sebagai berikut:

"Pembelajaran selama pandemi covid 19 menjadi efektif dengan memanfaatkan akun belajar id.kemdikbud karena penyampaian materi oleh guru melalui google meet dapat mendekatkan jarak antara guru di sekolah dan siswa di rumah. Selain itu pelaksanaan ulangan harian juga lebih mudah menggunakan google form. Siswa tidak perlu datang ke sekolah untuk mengerjakannya”.

Fitur-fitur workspace for education dapat diakses secara gratis dengan akun belajar.id kemdikbud. Kepemilikan dan keberhasilan aktivasi dari akun tersebut merupakan hal yang sangat penting. Siswa dengan inisial RRK memiliki akun belajar.id yang sudah diaktivasi dan dapat digunakan seperti yang disampaikan berikut ini:

"Iya, akun belajar.id kemdikbud sudah berhasil saya aktivasi sehingga bisa saya gunakan untuk pembelajaran bahasa Indonesia".

Narasumber dengan inisial RRK memiliki handphone android sendiri untuk menunjang pembelajaran daring selama pandemi covid 19 dengan memanfaatkan akun belejar.id kemdikbud seperti yang disampaikan berikut ini:

"Saya memiliki handphone android sendiri, pembelajaran bahasa Indonesia dapat saya ikuti dengan lancar menggunakan akun belajar.id kemdikbud".

Hasil wawancara tentang kelancaran pembelajaran bahasa Indonsia dengan memanfaatkan akun belajar.id kemdikbud seperti yang disampaikan narasumber dengan inisial RKK sebagai berikut:

"Saya dapat mengikuti pembelajaran bahasa Indonesia menggunakan akun akun belajar.id kemdikbud dengan lancar".

Narasumber berikutnya adalah siswa dengan inisial RAS. Pembelajaran Bahasa Indonesia dilaksanakan secara daring selama pandemi covid 19 dengan memanfaatkan akun belajar.id kemdikbud seperti yang disampaikan berikut ini:

"Saya menyukai pelajaran bahasa Indonesia. Pelajaran yang saya sukai adalah mengarang. Biasanya saya menggunakan waktu luang saya untuk mengarang". Pembelajaran bahasa Indonesia selama pandemi covid 19 dengan memanfaatkan akun belajar.id kemdikbud dapat terlaksana dengan lancar".

Narasumber RAS memberikan pendapatnya tentang keefektifan pembelajaran dengan memanfaatkan akun belajar.id kemdikbud sebagai berikt:

"Pembelajaran selama pandemi covid 19 menjadi efektif dengan memanfaatkan akun belajar id.kemdikbud karena penyampaian materi oleh guru melalui google meet dapat mendekatkan jarak antara guru di sekolah dan siswa di rumah. Selain itu pelaksanaan ulangan harian juga lebih mudah menggunakan google form. Siswa tidak perlu datang ke sekolah untuk mengerjakannya".

Fitur-fitur workspace for education dapat diakses secara gratis dengan akun belajar.id kemdikbud. Kepemilikan dan keberhasilan aktivasi dari akun tersebut merupakan hal yang sangat penting. Siswa dengan inisial RAS memiliki akun belajar.id yang sudah diaktivasi dan dapat digunakan seperti yang disampaikan berikut ini:

"Iya, saya sudah memiliki akun belajar.id kemdikbud dan sudah berhasil saya aktivasi sehingga bisa saya gunakan untuk pembelajaran bahasa Indonesia".

Narasumber dengan inisial RAS memiliki handphone android sendiri untuk menunjang pembelajaran daring selama pandemi covid 19 dengan memanfaatkan akun belejar.id kemdikbud seperti yang disampaikan berikut ini:

"Saya memiliki handphone android sendiri. Pembelajaran bahasa Indonesia dapat saya ikuti dengan lancar menggunakan akun belajar.id kemdikbud". 
Hasil wawancara tentang kelancaran pembelajaran bahasa Indonsia dengan memanfaatkan akun belajar.id kemdikbud seperti yang disampaikan narasumber dengan inisial RAS sebagai beriktu:

"Dengan menggunakan akun belajar.id kemdikbud, saya dapat mengikuti pembelajaran bahasa Indonesia dengan lancar".

Narasumber berikutnya adalah siswa dengan inisial RAW. Pembelajaran Bahasa Indonesia dilaksanakan secara daring selama pandemi covid 19 dengan memanfaatkan akun belajar.id kemdikbud seperti yang disampaikan berikut ini:

"Saya tidak terlalu menyukai pelajaran bahasa Indonesia. Karena saya merasa tidak mampu materi bahasa Indonesia. Meskipun begitu, saya tetap berusaha untuk memahami materi yang disampaikan guru dan saya juga tertib mengirim tugas yang diberikan guru ".

Narasumber RAW memberikan pendapatnya tentang keefektifan pembelajaran dengan memanfaatkan akun belajar.id kemdikbud sebagai berikt:

"Pembelajaran selama pandemi covid 19 menjadi efektif dengan memanfaatkan akun belajar id.kemdikbud karena penyampaian materi oleh guru melalui google meet dapat mendekatkan jarak antara guru di sekolah dan siswa di rumah. Selain itu pelaksanaan ulangan harian juga lebih mudah menggunakan google form. Siswa tidak perlu datang ke sekolah untuk mengerjakannya".

Fitur-fitur workspace for education dapat diakses secara gratis dengan akun belajar.id kemdikbud. Kepemilikan dan keberhasilan aktivasi dari akun tersebut merupakan hal yang sangat penting. Siswa dengan inisial RAW memiliki akun belajar.id yang sudah diaktivasi dan dapat digunakan seperti yang disampaikan berikut ini:

"Iya, saya sudah memiliki akun belajar.id kemdikbud dan sudah berhasil saya aktivasi sehingga bisa saya gunakan untuk pembelajaran bahasa Indonesia".

Narasumber dengan inisial RAW memiliki tidak memiliki handphone android sendiri namun handphone milik orang tuanya, untuk menunjang pembelajaran daring selama pandemi covid 19 dengan memanfaatkan akun belejar.id kemdikbud seperti yang disampaikan berikut ini:

"Saya tidak memiliki handphone android sendiri namun saya menggunakan handphone milik orang tua, meskipun begitu, pembelajaran bahasa Indonesia dapat saya ikuti dengan lancar menggunakan akun belajar.id kemdikbud".

Hasil wawancara tentang kelancaran pembelajaran bahasa Indonsia dengan memanfaatkan akun belajar.id kemdikbud seperti yang disampaikan narasumber dengan inisial RAW sebagai beriktu:

"Saya dapat mengikuti pembelajaran bahasa Indonesia menggunakan akun akun belajar.id kemdikbud dengan lancar".

Dukungan dari orang tua dalam pembelajaran secara daring sangatlah penting. Sarana pembelajaran daring yang sangat dibutuhkan adalah handphone atau lap top bagi anak-anak. Orang tua sudah membelikan anak-anak handphone sebelum pembelajaran di masa pandemi covid 19 sehingga anak-anak sudah mempunyai perangkat berupa lap top untuk mendukung pembelajaran daring dengan memanfaatkan akun belajar.id kemdikbud seperti hasil wawancara yang disampaikan oleh wali murid dengan inisial RP berikut ini:

"Anak saya sudah saya belikan handphone sebelum masa pandemi covid 19 sehingga pembelajaran daring selama pandemi covid 19 sudah tidak mengalami kendala perangkat untuk pembelajaran daring dengan memanfaatkan akun belajar.id kemdikbud".

Selain dukungan berupa kepemilikan kuota belajar. Sebelum adanya akun belajar.id kemdikbud, orang tua harus menyediakan paket data demi kelancaran pembelajaran daring. Namun setelah diterima akun belajar.id kemdikbud orang tua merasa terbantu karena siswa bisa mengakses layanan pembelajaran secara gratis, seperti yang disampaikan narasumber RP berikut ini:

"Alhamdulillah, dengan akun belajar.id kemdikbud anak saya bisa mengakses pembelajaran bahasa Indonesia secara gratis".

Selain perangkat berupa handphone atau lap top, pembelajaran daring sangat membutuhkan akses internet atau sinyal yang lancar sehingga ketika pembelajaran dengan google meet, siswa dapat mengikutinya dengan lancar. Kekuatan sinyal berhubungan dengan domisili siswa. Sebagian besar siswa kelas 6 berdomisili di kota sehingga tidak ada kendala tentang keterjangkauan sinyal. Berikut ini hasil 
wawancara dengan wali murid dengan inisial RP:

"Pembelajaran secara daring dapat di akses dengan lancar, tidak ada kendala dengan sinyal. Semua profider dapat diakses dengan lancar dari domisili kami”.

Pandemi covid 19 tetap menuntut guru dapat menyampaikan materi pembelajaran kepada siswa secara efektif, meskipun pembelajaran dilaksanakan secara daring dan antara guru dan siswa dapat terhubung seakan tanpa adanya jarak dan waktu. Dengan akun belajar.id kemdikbud guru dan siswa dapat melaksanakan pembelajaran dengan efektif. Efektif karena dapat menghemat waktu dan dapat mendekatkan jarak melalui pembelajaran dengan memanfaatkan workspace goodle for education yaitu google meet dan penilaian hasil belajar dengan google form seperti yang disampaikan narasumber dengan inisial RP berikut ini:

"Pembelajaran daring dengan google meet dan penilaian hasil pembelajaran dengan google form menggunakan akun belajar.id kemdikbud menjadikan pembelajaran lebih efektif karena guru dan siswa dapat melaksanakan pembelajaran secara jarak jauh tanpa harus bertemu di sekolah".

Narasumber RP menyadari bahwa pembelajaran daring bukan tanpa kendala. Kendala yang ditemukan adalah apabila siswa gagal login akun belajar.id kemdikbud. Namun kendala tersebut bisa diatasi seperti yang disampaikan narasumber dengan inisial RP sebagai berikut:

"Gagal aktivasi akun belajar.id kemdikbud bisa diatasi dengan menyampaikan masalah tersebut kepada guru selanjutnya guru menyampaikan masalah tersebut kepada admin sekolah. Dalam waktu 3 hari, admin sekolah sudah bisa mengaktifkan akun siswa yang gagal login".

Narasumber dengan inisial TA memberikan dukungan penuh pada anaknya supaya pembelajaran secara daring dapat terlaksana dengan lancar. Dukungan yang diberikan adalah membelikan perangkat pembelajaran yaitu handphone agar dapat memanfaatkan akun belajar.id kemdikbud seperti yang disampaikan berikut ini:

"Saya membelikan anak saya handphone baru supaya anak saya dapat mengikuti pembelajaran secara daring dengan memanfaatkan akun belajar.id kemdikbud dengan lancar".

Diterimanya akun belajar.id kemdikbud, orang tua merasa senang karena siswa bisa mengakses layanan pembelajaran secara gratis, seperti yang disampaikan narasumber TA berikut ini:

"Bersyukur, anak saya dapat mengakses pembelajaran secara gratis dengan akun belajar.id kemdikbud".

Pembelajaran daring juga membutuhkan akses sinyal yang lancar. Narasumber TA menyampaikan pendapatnya sebagai berikut:

"Domisili kami berada di tengah kota sehingga sinyal dapat kami akses dengan mudah".

Tentang keefektifam pembelajaran daring yang disampaikan guru selama pandemi covid 19, narasumber dengan inisial TA menyampaikan pendapatnya sebagai berikut:

"Guru dan siswa tidak perlu bertemu langsung di sekolah karena pembelajaran selama pandemi covid 19 tidak boleh dilaksanakan di sekolah. Guru menyampaikan materi pembelajaran lebih efektif karena memanfaatkan google meet dan penilaian hasil pembelajaran dilaksanakan melalui google form menggunakan akun belajar.id kemdikbud".

Narasumber TA menyadari bahwa pembelajaran daring bukan tanpa kendala. Namun menurut narasumber, selama pembelajaran daring tidak mengalami kendala yang berarti seperti yang disampaikan sebagai berikut:

"Anak kami tidak mengalami kendala dalam mengikuti pembelajaran daring dengan memanfaatkan akun belajar.id kemdikbud".

Narasumber selanjutnya adalah dengan inisial SRS memberikan dukungan penuh pada anaknya sehingga pembelajaran secara daring dapat terlaksana dengan lancar. Terlebih diterimanya akun belajar.id kemdikbud, orang tua merasa senang karena siswa bisa mengakses layanan pembelajaran secara gratis, seperti yang disampaikan narasumber SRS berikut ini:

"Sangat bersyukur karena anak saya dapat mengakses pembelajaran secara gratis dengan akun belajar.id kemdikbud".

Akun belajar.id kemdikbud menjadikan pembelajaran menjadi efektif di masa pandemi covid 19 seperti sekarang ini karena adanya SOP yaitu tidak diberi izin bagi guru dan siswa untuk melaksanakan pembelajaran di sekolah sehingga dengan akun belajar.id kemdikbud pembelajaran dapat terlaksanan 
dengan efektif karena pembelajaran dapat dilaksanakan tanpa adanya batasan ruang dan waktu. Materi disampaikan dengan google meet sedangkan penilaoan harian dilaksanakan dengan google form seperti yang disampaikan narasumber dengan inisial SRS sebagai berikut:

"Guru dan siswa tidak perlu bertemu langsung di sekolah karena pembelajaran selama pandemi covid 19 tidak boleh dilaksanakan di sekolah. Guru menyampaikan materi pembelajaran lebih efektif karena memanfaatkan google meet dan penilaian hasil pembelajaran dilaksanakan melalui google form menggunakan akun belajar.id kemdikbud".

Narasumber SRS menyadari bahwa pembelajaran daring bukan tanpa kendala. Secara umum kendala yang dihadapi siswa adalah sinyal yang kurang bersahabat, namun tempat tinggal kami berada di kota sehingga tidak ada masalah sinyal. Pembelajaran daring dengan akun belajar.id kemdikbud tidak mengalami kendala yang berarti seperti yang disampaikan sebagai berikut:

"Tidak ada kendala yang berarti selama anak kami mengikuti pembelajaran daring dengan memanfaatkan akun belajar.id kemdikbud".

Narasumber dengan inisial NP selalu memantau pembelajaran anaknya selama pandemi covid 19 dengan memanfaatkan akun belajar.id kemdikbud. Sesuai pantauannya pembelajaran secara daring dapat terlaksana dengan lancar dengan memanfaatkan akun belajar.id kemdikbud, seperti yang disampaikan narasumber SRS berikut ini:

"Pembelajaran bahasa Indoensia selama pandemi covid 19 dapat terlaksanan dengan lancar memanfaatkan akun belajar.id kemdikbud".

Pembelajaran selama pandemi covid 19 membutuhkan strategi pembelajaran yang sesuai dengan kondisi sehingga pembelajaran dapat dilaksanakan dengan efektif. Guru dan siswa untuk melaksanakan pembelajaran di sekolah sehingga dengan akun belajar.id kemdikbud pembelajaran dapat terlaksanan karena pembelajaran dapat dilaksanakan tanpa adanya batasan ruang dan waktu. Materi disampaikan dengan google meet sedangkan penilaoan harian dilaksanakan dengan google form seperti yang disampaikan narasumber dengan inisial NP sebagai berikut:

"Selama pandemi covid 19, guru dan siswa tidak perlu bertemu langsung di sekolah karena pembelajaran tidak boleh dilaksanakan di sekolah. Guru menyampaikan materi pembelajaran menjadi lebih efektif karena memanfaatkan google meet dan penilaian hasil pembelajaran dilaksanakan melalui google form menggunakan akun belajar.id kemdikbud".

Kendala yang dihadapi selama pembelajaran daring, Narasumber NP mengatakan bahwa jaringan internet di tempat tinggalnya tidak ada masalah sinyal. Pembelajaran daring dengan akun belajar.id kemdikbud tidak mengalami kendala yang berarti seperti yang disampaikan sebagai berikut:

"Sinyal di rumah kami tidak ada kendala yang berarti sehingga pembelajaran anak kami selama daring dengan memanfaatkan akun belajar.id kemdikbud dapat terlaksana dengan lancar".

Narasumber dengan inisial AS selalu mendampingi pembelajaran anaknya selama pandemi covid 19. Pembelajaran bahasa Indonesia secara daring dapat terlaksana dengan lancar dengan memanfaatkan akun belajar.id kemdikbud, seperti yang disampaikan narasumber AS berikut ini:

"Pembelajaran bahasa Indoensia selama pandemi covid 19 dapat terlaksanan sangat lancar dengan memanfaatkan akun belajar.id kemdikbud".

Pembelajaran yang sesuai dengan kondisi pandemi covid 19 dapat dilaksanakan dengan efektif. Guru dan siswa tidak perlu melaksanakan pembelajaran di sekolah sehingga dengan akun belajar.id kemdikbud pembelajaran dapat terlaksanan karena pembelajaran dapat dilaksanakan tanpa adanya batasan ruang dan waktu. Materi disampaikan dengan google meet sedangkan penilaoan harian dilaksanakan dengan google form seperti yang disampaikan narasumber dengan inisial AS sebagai berikut:

"Guru menyampaikan materi pembelajaran menjadi lebih efektif karena memanfaatkan google meet dan penilaian hasil pembelajaran dilaksanakan melalui google form menggunakan akun belajar.id kemdikbud".

Selama pembelajaran daring menurut Narasumber AS mengatakan bahwa jaringan internet di tempat tinggalnya tidak ada masalah sinyal. Pembelajaran daring dengan akun belajar.id kemdikbud tidak mengalami kendala yang berarti seperti yang disampaikan sebagai berikut:

"Sinyal di rumah kami tidak ada kendala yang berarti sehingga pembelajaran anak kami selama daring 
dengan memanfaatkan akun belajar.id kemdikbud dapat terlaksana dengan lancar”.

\section{PEMBAHASAN}

Perkembangan Ilmu Pengetahuan dan Teknologi (IPTEK) dapat mendorong upaya-upaya pembaharuan dalam pemanfaatan hasil-hasil teknologi dalam proses belajar. Para guru dituntut untuk mampu memanfaatkan alat-alat hasil perkembangan tekonologi dalam pembelajaran karena sudah menjadi bagian dari perkembangan bahkan tuntutan zaman.

Dalam rangka menjamin kelancaran proses pembelajaran, memudahkan pendidik dan peserta didik mengakses layanan pembelajaran, Kementrian Pendidikan dan Kebudayaan (Kemendikbud) melalui Pusat Data dan Teknologi Informasi (Pusdatin) meluncurkan akun pembelajaran dengan domain belajar.id. Akun elektronik tersebut dapat digunakan oleh peserta didik, pendidik, dan tenaga kependidikan untuk mengakses layanan pembelajaran berbasis elektronik.

Merujuk pada Surat Edaran Nomor 37 tahun 2020 tentang Akun Akses Layanan Pembelajaran bagi peserta didik, pendidik, dan Tenaga Kependidikan, peluncuran akun belajar juga bertujuan untuk menjamin kelancaran proses pembelajaran, memudahkan pendidik dan peserta didik mengakses layanan pembelajaran. Peraturan Sekretaris Jendral Kementrian Pendidikan dan Kebudayaan Nomor 18 Tahun 2020 tentang Petunjuk Teknis Pemanfaatan Data Pokok Pendidikan untuk Akun Akses Layanan Pembelajaran. Menurut Kementrian Pendidikan dan Kebudayaan (2020: 2) bahwa akun Pembelajaran merupakan akun elektronik dengan domain belajar.id yang diterbitkan oleh Kementerian Pendidikan dan Kebudayaan dan dapat digunakan oleh peserta didik, pendidik, dan tenaga kependidikan sebagai akun untuk mengakses aplikasi pembelajaran berbasis elektronik.

Pelaksanaan pembelajaran secara daring dengan memanfaatkan akun belajar id.Kemdikbud menjadikan pembelajaran lebih efektif karena antara guru dan siswa tidak harus bertatap muka di sekolah untuk bisa berinteraksi dalam pembelajaran. Permasalahan yang ditemukan selama proses pembelajaran dengan memanfaatkan akun belajar.id kemdikbud juga bisa diatasi yaitu ada siswa yang gagal login akun belajar.id kemdikbud dan bisa diatasi oleh operator sekolah dengan mereset akun tersebut.

Berikut ini adalah penelitian yang terkait dengan pembelajaran selama pandemi covid 19 dengan memanfaatkan portal rumah belajar yaitu portal sebagai sumber belajar yang diluncurkan oleh Kemendikbud dan bisa dimanfaatkan oleh guru dalam pembelajaran daring. Penelitian tersebut sejenis dengan penelitian dilakukan peneliti yaitu pelaksanaan pembelajaran daring dengan memanfaatkan akun belajar.id kemdikbud.

Supandri (2018) sudah terlebih dahulu melakukan penelitian tentang portal rumah belajar dengan judul "Faktor-Faktor Penyebab Guru n-1.... Optimal Memanfaatkan Portal Rumah Belajar Dalam Kegiatan Pembelajaran" dengan metoc 106 litian deskriptif kualitatif. Variabel penelitian Supandri adalah pemanfaatan portal rumah belajar yang belum optimal dalam kegiatan pembelajaran. Kementrian Pendidikan dan Kebudayaan menurunkan kebijakan-kebijakan tentang pelaksanaan pembelajaran yaitu dengan daring dengan tujuan memutus matarantai penyebaran covid 19.

Pelaksanaan pembelajaran daring sangat dipengaruhi dari kemampuan dari pendidik dalam hal pemanfaatan teknologi serta fitur-fitur yang disediakan oleh Kementrian. Manakala diamati secara seksama, pengaruh/dampak kemajuan TIK yang sangat pesat sangat dirasakan di dalam kehidupan seharihari di bidang pemberitaan/informasi yang memungkinkan orang dapat berkomunikasi dengan mudah, cepat, dan relatif murah (Supandri, 2018: 2); dan demikian juga di bidang sistem pendidikan (Supandri, 2018: 2). Namun menurut Indriyanto, dampak positif pemanfaatan kemajuan TIK masih belum tampak pada dunia pendidikan (Supandri, 2018: 2). Sekalipun dikatakan belum tampak dampak positifnya, tetapi berbagai upaya pemanfaatan TIK di bidang pendidikan/pembelajaran telah dimulai secara bertahap dan berkelanjutan. Tidak hanya terbatas pada lembagalembaga pendidikan di daerah perkotaan dan pedesaan saja yang memanfaatkan kemajuan TIK tetapi secara bertahap juga telah mulai dilaksanakan oleh sekolahsekolah yang terdapat di daerah-daerah terdepan, terluar, dan tertinggal (Supandri, 2018: 2). 
Lebih jauh dikemukakan Siahaan bahwa pemanfaatan TIK secara arif (terencana, terpadu, dan teratur) dapat memfasilitasi kegiatan pembelajaran, tidak hanya (1) memberikan kemudahan bagi guru dalam membelajarkan peserta didiknya, (2) menjadikan konkrit berbagai uraian objek yang bersifat abstrak, (3) memvisualisasikan secara animatif tahap-tahapan suatu proses atau siklus, tetapi juga (4) meningkatkan efisiensi penggunaan waktu guru untuk menyelenggarakan kegiatan pembelajaran termasuk pemberian berbagai penjelasan (Supandri, 2018: 3).

Seiring dengan kemajuan TIK ini, peran guru telah mengalami perubahan dari yang semula sebagai penyampai pengetahuan, sumber utama informasi, ahli materi, dan sumber segala jawaban menjadi sebagai fasilitator pembelajaran, pelatih, kolaborator, navigator pengetahuan, dan mitra belajar peserta didik (Supandri, 2018: 7). Di samping itu, guru juga bergeser perannya dari yang semula mengendalikan dan mengarahkan semua aspek pembelajaran, menjadi lebih banyak memberikan alternatif dan tanggung jawab kepada peserta didik dalam proses pembelajaran (Supandri, (2018: 7). Guru tidak lagi menjadi satu-satunya orang yang paling tahu terhadap berbagai informasi dan pengetahuan yang berkembang (Supandri, 2018: 7) . Lebih jauh dikemukakan Warsihna bahwa dengan hadirnya Portal "Rumah Belajar" di blantika dunia maya (internet) telah turut menambah khasanah sumber belajar bagi dunia pendidikan di Indonesia.

Kehadiran Portal ini akan memudahkan guru untuk membuat pembelajaran menjadi lebih menarik karena tersedia berbagai komponen yang diperlukan untuk pembelajaran, baik di kelas maupun di luar kelas, terutama penugasan kepada peserta didik agar mereka sedini mungkin mengenal teknologi. Sebagaimana yang telah dikemukakan sebelumnya bahwa Kementerian Pendidikan dan Kebudayaan melalui Pusat Teknologi Informasi dan Komunikasi Pendidikan dan Kebudayaan (Pustekkom Kemdikbud) telah mengembangkan sebuah fasilitas layanan pembelajaran yang terintegrasi dengan pengembangan inovasi pembelajaran dan pembinaan profesionalitas guru disebut sebagai Portal Rumah Belajar (Portal Rumbel) pada tahun 2011 Kemdikbud (dalam Supandri, 2018: 7 ).

Persamaan penelitian Supandri (2018) dengan peneliti terletak pada variabel pembelajaran daring. Sedangkan perbedaannya, Supandri meneliti sebelum masa pandemi covid-19 dengan portal rumah belajar dan peneliti melakukan penelitian pada masa pandemi covid-19 dengan menggunakan akun belajar.id Kemdikbud.

Terhitung semenjak bulan Maret lalu Pembelajaran Daring Sebagai Upaya Study From Home (SFH)..... Jurnal Pendidikan Administrasi Perkantoran (JPAP) Volume 8, Nomor 3, 2020497 dampak yang diberikan covid 19 pada kegiatan belajar mengajar cukup terasa, hal tersebut terlihat dari pembelajaran yang semestinya dilakukan secara langsung dan bermakna sekarang hanya dapat dilakukan secara mandiri. Dengan begitu peserta didik melakukan pembelajaran tidak langsung dengan memanfaatkan pembelajaran dalam jaringan atau daring yang dirasa cukup tepat guna di situasi seperti saat ini (Handarini, 2020: 496).

Pembelajaran yang dilaksanakan oleh peneliti sesuai dengan yang disampaikan Handarini (2020:496) dalam artikelnya yaitu pembelajaran daring yang dirasa cukup tepat guna dalam situasi pandemi Covid19.

Portal Rumah Belajar dapat diakses melalui domain akun belajar.id Kemdikbud khususnya untuk pembelajaran Bahasa Indonesia. Bahasa Indonesia adalah mata pelajaran yang resmi di negara Indonesia (Sulfemi, dkk, 2020: 272). Persamaan penelitian yang dilakukan oleh Sulfemi, dkk (2020) terletak pada variabel penelitian yaitu penggunaan media dalam pembelajaran bahasa Indonesia. Sedangkan perbedaannya Sulfemi, dkk (2020) merupakan penelitian deskriptif kuantitatif dengan menggunakan media kartu dalam pembelajaran bahasa Indonesia dan peneliti menggunakan metode deskriptif kualitatif dengan menggunakan media akun belajar.id kemdikbud.

Assiqi, Sumarmi (2020) mengadakan penelitian yang berjudul "Pemanfaatan Platform Digital di Masa Pandemi Covid-19' menjelaskan bahwa pembelajaran daring merupakan proses pembelajaran yang memanfaatkan jaringan internet dalam proses pembelajaran (Isman, 2017). Pembelajaran daring memberikan kesempatan peserta didik belajar dengan keleluasaan waktu belajar serta dimanapun peserta didik dan guru berada. Peserta didik dapat berinteraksi dengan guru menggunakan beberapa aplikasi seperti classroom, video converence, telepon atau live chat, zoom maupun melalui whatsapp group. Proses pembelajaran daring merupakan pembelajaran yang keberhasilannya akan sangat dipengaruhi oleh kemampuan guru menggunakan teknologi dalam menyampaikan materi pembelajaran. Data studi literature 
tentang penyampaian materi secara e-learning menunjukkan bahwa tidak semua peserta didik akan sukses dalam pembelajaran online (Nakayama et al., 2006 dalam Assiqi, Sumarni).

Persamaan penelitian yang dilakukan oleh Assidiqi, Sumarni (2020) terletak pada pemanfaatan internet dalam pembelajaran daring. Sedangkan perbedaannya Assidiqi, Sumarmi (2020) menjelaskan tentang platform digital yang digunakan dalam pembelajaran sedangkan peneliti menggunakan akun belajar.id Kemdikbud untuk megakses google meet dan google form dalam pembelajaran.

Ulum, dkk (2019) mengadakan penelitian yang berjudul "Pemanfaatan Google Apps di era literasi digital pada siswa Sekolah Dasar (SD)". Metode penelitian menggunakan penelitian deskriptif kualitatif dengan teknik pengumpulan data menggunakan studi kepustakaan. Literasi digital merupakan kemampuan penggunaan teknologi informasi dari perangkat digital secara efektif efisien dalam berbagai konteks kehidupan sehari-hari. Salah satu upaya literasi digital adalah pemanfaatan teknologi informasi menggunakan Google Apps for education yang telah disediakan oleh perusahaan mesin pencari google untuk segenap komponen pendidikan disekolah. Dengan memanfaatkan Google Apps dalam proses pembelajaran yang dapat dibuka melalui smartphone dan tablet, memungkinkan para guru menyiapkan dan menyajikan materi pembelajarannya secara online (dan offline) yang mudah diakses siswa.

Persamaan penelitian yang dilakukan Ulum, dkk (2019) terletak pada kemampuan penggunaan teknologi informasi dari perangkat digital untuk mengembangkan literasi digital sedangkan kebaruan dalam penelitian ini adalah peneliti memanfaatkan teknologi informasi untuk mengakses akun belajar.id Kemdikbud yang dimanfaatkan dalam pembelajaran di era pandemi covid 19.

Kurniawansyah, Siswanto (2020) melakukan penelitian yang berjudul "Kolaborasi Whatsapp Group, Zoom Cloud Meeting, Dan Google Drive Sebagai Formula Dalam Pelaksanaan Kegiatan Perkuliahan Online Di Masa Pandemi Covid-19" menyebutkan bahwa dunia Pendidikan menghadapi tantangan besar dengan adanya Pandemi Covid-19 ini. Semua kegiatan Perkuliahan yang biasanya dengan tatap muka, sekarang dilarang dan harus melaksanakan kegiatan secara daring atau online. Banyak Aplikasi yang ditawarkan dalam melaksanakan perkuliahan secara online, seperti Zoom, Google Meeting, Whatsapp Group, dan Google Drive dan lain-lain. Dosen dan mahasiswa harus mampu dan melek Teknologi, kalau salah satu ada yang tidak bisa memanfaatkan Teknologi, maka akan sulit untuk terlaksana kegiatan Perkuliahan onlinenya.

Salah satu media pembelajaran berbasis teknologi yang dapat dijadikan sebagai penunjang pada media yang sudah ada adalah dalam bentuk e-learning (pembelajaran elektronik). E-learning merupakan aplikasi internet yang dapat menghubungkan peserta didik dan pendidik dalam sebuah ruang belajar online. $E$ learning didesain untuk mengatasi keterbatasan antara pendidik dan pesrta didik, terutama dalam hal waktu, ruang kondisi, dan keadaan. Ringkasnya, e-learning dapat menciptakan sebuah ruang digital pembelajaran, dimana peserta didik dapat mengakses materi dari berbagai sumber tanpa dibatasi ruang dan waktu. (Kurniawansyah, Siswanto: 2020).

Kemudahan dan kenyaman berkomunikasi ini tidak serta merta memberikan pemahaman yang baik bagi penggunanya mengenai manfaat dan adab atau dalam istilah dunia maya disebut Nettiquette. Nettiqutte dapat didefinisikan sebagai adab dalam ber-Social Media. Tingkat pemahaman mengenai manfaat dan adab menimbulkan berbagai macam dampak penggunaan aplikasi WhatsApp Messenger. Layanan yang paling banyak digunakan melalui aplikasi WhatsApp Messenger adalah percakapan kelompok atau Group Discussion. (Kurniawansyah, Siswanto: 2020)

Persamaan penelitian yang dilakukan oleh Kurniawansyah, Siswanto (2020) terletak pada media pembelajaran berbasis teknologi yang dapat dijadikan sebagai penunjang pada media yang sudah ada adalah dalam bentuk e-learning (pembelajaran elektronik). Kurniawansyah, Siswanto (2020) pembelajaran dilaksanakan dengan memanfaatkan platform yang disediakan e learning seperti seperti Zoom, Google Meeting, Whatsapp Group, dan Google Drive dan lain-lain sedangkan kebaruan peneliti adalah memanfaatkan akun belajar.id Kemdikbud dan platform yang digunakan adalah Google Meet dan Google Form.

Wibowo, dkk (2014) mengadakan penelitian yang berjudul "Pengembangan LMS (Learning Management System) Berbasis Web untuk Mengukur Pemahaman Konsep dan Karakter Siswa”. Dalam penelitian tersebut diungkapkan bahwa kemajuan teknologi informasi yang pesat mendukung 
terselenggaranya pembelajaran berbasis elektronik (e-learning). E-learning memiliki sejumlah keuntungan diantaranya peserta didik dapat saling berbagi informasi dan dapat mengakses bahan-bahan belajar setiap saat dan evaluasi yang dapat mengukur pemahaman konsep siswa. Dengan kondisi seperti ini peserta didik diharapkan dapat memantapkan pemahaman konsep terhadap materi pembelajaran. E-learning dapat melatih kemandirian siswa dalam teknis dan pengalaman menggunakannya. Selain itu, e-learning juga dapat membantu guru dalam memantau keaktifan siswa dengan berbagai penugasan yang diberikan, forum diskusi maupun aktivitas yang lain, sehingga karakter siswa dapat dideskripsikan melalui e-learning.

Wibowo, dkk (2014) menuliskan bahwa e-learning yang mampu meningkatkan kemampuan kognitif siswa adalah $e$-learning yang mempunyai tingkat interaktifitas pengguna tinggi, yang selain menyajikan materi pembelajaran dalam bentuk file baik itu dalam format words, powerpoint, html atau PDF tapi $e$ learning tersebut juga mempunyai nilai lebih menu yang lebih bersifat interaktif, baik itu dalam bentuk evaluasi online yang lebih bervariasi, konsultasi online maupun fasilitas chatting. Di dalam e-learning terdapat kelas virtual yang mampu menampung guru dan siswa untuk dapat berinteraksi dan membuat laboraturium virtual dengan menyisipkan media berupa gambar animasi sehingga guru dapat melakukan demonstarsi melalui media tersebut. Hasil penelitian yang dilakukan menyatakan laboratorium virtual dapat mendukung kegiatan praktikum di laboratorium yang bersifat interaktif, dinamis, animatif dan berlingkungan virtual sehingga tidak membosankan dan dapat mendukung keinginan pengguna untuk mempelajari dan memahami materi secara efektif serta memfasilitasi pendidikan karakter siswa.

Saat ini sudah cukup banyak instansi atau lembaga yang menggunakan e-learning sebagai sarana pembelajarannya, penggunaan e-learning dalam pembelajaran terbukti sukses. Dalam penelitian, pembelajaran menggunakan e-learning sangat efektif saat dipadukan dengan metode pembelajaran inkuiri terbimbing. Berdasarkan permasalahan di atas telah dijelaskan bahwa e-learning dapat dijadikan sebuah inovasi pembelajaran yang dapat meringankan beban guru dalam mengajar. Tujuan dari penelitian ini adalah mengembangkan Software Learning Management System, mendapatkan tanggapan penggunaan dan menguji keefektifannya dalam meningkatkan pemahaman konsep serta mengembangkan karakter siswa Wibowo, dkk (2014).

Persamaan penelitian yang dilakukan oleh Wibowo, dkk (2014) adalah mengembangkan Software Learning Management System Sedangkan kebaruan penelitian ini adalah Wobowo, dkk (2014) memadukan pembelajaran e learning dengan metode pembelajaran inkuiri terbimbing sedangkan peneliti melaksanakan pembelajaran secara daring dengan memanfaatkan platform akun belajar.id Kemdikbud.

Sadikin, Hamidah (2020) melakukan penelitian yang berjudul "Pembelajaran Daring di Tengah Wabah Covid-19”. Pademi covid-19 telah mengganggu proses pembelajaran secara konvensional. Maka diperlukan solusi untuk menjawab permasalahan tersebut. Pembelajaran secara daring adalah salah satu alternatif yang dapat mengatasi masalah tersebut. Tujuan penelitian adalah untuk memperoleh gambaran pelaksanaan pembelajaran daring di Prodi Pendidikan Biologi FKIP Universitas Jambi sebagai upaya menekan penyebaran covid-19 di Perguruan Tinggi. Subjek penelitian adalah mahasiswa Prodi Pendidikan Biologi. Data dikumpulkan dengan wawancara melalui zoom cloud meeting. Analisis data dilakukan menggunakan teknik analisis interaktif Miles \& Huberman.

Persamaan penelitian yang dilakukan Sadikin, Hamidah (2020) adalah pembelajaran daring di tengah wabah covid 19 dengan memanfaatkan google aplication. Perbedaannya, Sadikin, Hamidah (2020) mengulas juga tentang mahalnya biaya yang dikeluarkan untuk mengakses aplikasi yang digunakan untuk pembelajaran. Peneliti membahas tentang pemanfaatan akun belajar.id Kemdikbud untuk mengakses aplikasi-aplikasi untuk pembekajaran secara gratis.

Langi, dkk mengadakan penelitian yang berjudul "Pengaruh Komunikasi Media Online Aplikasi Ruang Guru Pt. Ruang Raya Indonesia Terhadap Peningkatan Prestasi Belajar Siswa Sma Negeri 1 Manado". Persamaan penelitin ini adalah memanfaatkan media online aplikasi Ruang Guru Pt. Ruang Guru Indonesia. Perbedaannya adalah peneliti memanfaatkan akun belajar.id Kemdikbud yang dikeluarkan oleh Kemdikbud untuk kelancaran guru dalam melaksanakan pembelajaran daring.

Fitria, Lestari (2017) mengadakan penelitian yang berjudul "Penerapan Media Pembelajaran Google Drive dalam Pembelajaran Bahasa Indonesia". Persamaan penelitian ini adalah pemanfaatan aplikasi google drive sebagai layanan penyimpanan daring milik google. Penelitian ini difokuskan pada 
pemanfaatan Google Doc, merupakan aplikasi Google yang berkaitan dengan editing teks mirip dengan MS Word.

Perbedaan penelitian ini dengan penelitian yang dilakukan peneliti adalah penerapan media pembelajaran Google Drive terhadap hasil belajar Bahasa Indonesia adalah untuk memperbaiki dan meningkatkan kondisi serta kualitas pembelajaran yang kreatif dan inovatif di kelas serta Meningkatkan layanan profesional dalam konteks pembelajaran di kelas. Sedangkan akun belajar.id Kemdikbud merupakan akun yang dapat kita akses untuk membuka platform-platform termasuk membuka google drive.

Sudah banyak penelitian tentang pelaksanaan pembelajaran pada masa pandemi covid-19. Namun, belum ada penelitian yang mengkaji tentang pemanfaatan akun belajar.id Kemdikbud. Inovasi pembelajaran tersebut diluncurkan oleh Kementrian Pendidikan dan Kebudayaan untuk menunjang kelancaran pembejaran pada masa pandemi covid-19. Oleh karena itu, peneliti fokus pada pemanfaatan domain akun belajar.di Kemdikbud dalam pembelajaran bahasa Indonesia kelas 6 SDN Margomulyo 1 Ngawi. Saat ini adalah satu-satunya penelitian yang mengkaji pemanfaatan domain akun belajar.id Kemdikbud.

\section{SIMPULAN}

Berdasarkan diskripsi data yang telah dijabarkan sebelumnya, terdapat beberapa hal yang bisa dibahas pada penelitian ini.

Pembelajaran bahasa Indonesia dengan memanfaatan akun belajar.id Kemdikbud.

Mendasar pada SOP (Standar Opersional Prosedur) yang dikeluarkan pemerintah untuk mengatur semua rakyat Indonesia, baik masyarakat awam, para tenaga medis, pengusaha, dan lain-lain untuk meredakan persebaran virus Corona, pembelajaran bahasa Indonesia kelas 6 SDN Margomulyo 1 Ngawi Tahun Pelajaran 2020/2021 dilaksanakan sepenuhnya secara daring dengan memanfaatkan akun belajar.id Kemdikbud.

Pemanfaatan akun belajar id.Kemdikbud pada pembelajaran bahasa Indonesia untuk mengakses workspace for education yaitu google meet untuk penyampaian materi dari guru dan google form untuk penilaian harian.

Keefektifan Pembelajaran bahasa Indonesia dengan memanfaatkan akun belajar.id Kemdikbud

Pembelajaran secara daring dengan memanfaatkan akun belajar.id Kemdikbud membuat pembelajaran bahasa Indonesia menjadi efektif karena guru dapat menyampaikan materi pelajaran dengan menggunakan google meet. Guru dan siswa dapat bertatap muka melalui google meet untuk melaksanakan pembelajaran. Guru di sekolah sedangkan siswa di rumah masing-masing. Efektif ruang dan waktu. Begitu juga dengan penilaian harian menggunakan google form, guru memandu penilaian dari sekolah dan siswa dapat mengerjakan penilaian dari rumah.

Permasalahan yang dihadapi selama memanfaatkan akun belajar.id Kemdikbud

Diakui pembelajaran secara daring bukan tanpa kendala. Namun berdasarkan hasil wawancara dengan narasumber, pembelajaran daring dapat terlaksana tanpa ada kendala yang berarti. Kendala akun belajar.id kemdikbud sudah bisa diatasi dengan melaporkan kepada admin sekolah dan selanjutnya disampaikan kepada admin pusat minta untuk direset ulang. Kendala yang sering terjadi pada pembelajaran daring adalah sinyal yang kurang mendukung, namun tidak demikian dengan pembelajaran di kelas 6 SDN Margomulyo 1 karena domisili siswa berada di dalam kota sehingga tidak masalah dengan sinyal.

Berdasarkan hasil penelitian, pembelajaran dengan memanfaatkan akun belajar.id kemdikbud dapat terlaksanan dengan lancar. Meski ada kendala namun kendala tersebut dapat diatasi dengan cepat sehingga tidak mengganggu pembelajaran secara daring.

Saran yang dapat peneliti sampaikan tentang pemanfaatan akun belajar.id kemdikbud dalam pembelajaran adalah guru dan siswa dapat memanfaatkan semua fitur-fitur yang ada dalam workspace for education sehingga pembelajaran semakin mudah dan menyenangkan. 


\section{DAFTAR PUSTAKA}

Assidiqia, M.H, Sumarni, W. (2020). Pemanfaatan Platform Digital di Masa pandemi Covid-19, UNNES, Buana, D.R. (2020). Analisis Perilaku Masyarakat Indonesia dalam Menghadapi Pandemi Virus Corona (Covid-19) dan Kiat Menjaga Kesejahteraan Jiwa,

Fitria, F., Listari, (2017). Penerapan Media Pembelajaran Google Drive dalam Pembelajaran Bahasa Indonesia, Jurnal Penelitian Pendidikan Bahasa dan Sastra,

Hadi, S. (2014). Penelitian Research. Yogyakarta: BPFE. Indonesia,

Hamalik, Oemar. (2013). Proses Belajar Mengajar. Jakarta: PT Bumi Aksara,

Huberman, M (2012). Analisis Data Kualitatif. Jakarta: Penerbit Universitas Indonesia,

Kurniawansyah, A.S., Siswanto. (2020). Kolaborasi Whatsapp Group, Zoom Cloud Meeting, dan Google Drive debagai Formula dalam Pelaksanaan Kegiatan Perkuliahan Online di Masa Pandemi Covid19, Jurnal Media Infotama,

Rahmat, P.S. (2009). Penelitian Kualitatif, Equilibrium, 5(9): 1-8.

Rulam, A, (2005). Memahami Metodologi Penelitian Kualitatif. Malang: UM PREES

Sadikin, A., Hamidah, A., (2020). Pembelajaran Daring di Tengah Wabah Covid-19, Jurnal Imiah Pendidikan Biologi (BIODIK),

Sugiyono. (2018). Metode Penelitian Kualitatif. Bandung: Alfabeta.

Sulfemi, W.B., Siswanto, Heryadi. T., Soleh, A.N. (2020). Model Project Based Learning Berbantu Media Kartu dalam Pembelajaran Bahasa Indonesia Materi Kalimat Eefektif Pada Surat Undangan, Metalingua,

Supandri. (2018). Faktor-Faktor Penyebab Guru Belum Optimal Memanfaatkan Portal Rumah Belajar dalam Kegiatan Pembelajaran, Teknodik,

Ulum, B., Fantiro, F.A., Rifa'I, M.N. (2019). Pemanfaatan Google Apps Di Era Literasi Digital Pada Siswa Sekolah Dasar, Lentera,

Wibowo, A.T., Akhlis, I., Nugroho, S.E.. (2014). Pengembangan LMS (Learning management Sistem) Berbasis Web untuk Mengukur Pemahaman Konsep dan Karakter Siswa, Scientific Journal of Informatics,

Wicaksana, M.F., dan Meikayanti, E.A. (2014). vvıodel Pembelajaran Keterampilan Berbicara di SMP dengan Mengangkat Kepopuleran Kepahlawanan Lokal, Widyabrasta,

Wulandari, A., Harjono, H.S., Budiyono, H. (2019). Pengaruh Media Digital Storytelling terhadap Hasil Belajar Mahasiswa S-1 PBSI Universitas Jambi DIKBASTRA 2 (2): 